Article

\title{
Late Miocene-Early Pliocene Out-of-Sequence Thrusting in the Southern Apennines (Italy)
}

\author{
Stefano Vitale 1,*(1), Ernesto Paolo Prinzi ${ }^{1}$, Francesco D'Assisi Tramparulo ${ }^{2}$, Claudio De Paola 1,3, \\ Rosa Di Maio ${ }^{1}$, Ester Piegari ${ }^{1}\left(\mathbb{D}\right.$, Monia Sabbatino ${ }^{1}{ }^{\circledR}$, Jacopo Natale $\left.{ }^{1} \mathbb{(}\right)$, Pasqualino Notaro ${ }^{4}$ \\ and Sabatino Ciarcia ${ }^{5}$ \\ 1 Dipartimento di Scienze della Terra, dell'Ambiente e delle Risorse (DiSTAR), \\ Università degli Studi di Napoli Federico II, 80126 Napoli, Italy; prinziernesto@gmail.com (E.P.P.); \\ Claudio.DePaola@socotec.com (C.D.P.); rosa.dimaio@unina.it (R.D.M.); ester.piegari@unina.it (E.P.); \\ monia.sabbatino@unina.it (M.S.); jacopo.natale@unina.it (J.N.) \\ 2 Istituto Nazionale di Geofisica e Vulcanologia, sezione di Napoli Osservatorio Vesuviano, \\ 80124 Napoli, Italy; francesco.tramparulo@ingv.it \\ 3 SOCOTEC Italia s.r.l., Lainate, 20045 Milano, Italy \\ 4 EalCUBO (Environment, Earth, Engineering) Soc. Coop., Arcavacata, 87063 Cosenza, Italy; \\ pasqualino.notaro@gmail.com \\ 5 Dipartimento di Scienze e Tecnologie, Università degli Studi del Sannio, 82100 Benevento, Italy; \\ sabatino.ciarcia@unisannio.it \\ * Correspondence: stefano.vitale@unina.it
}

Received: 4 July 2020; Accepted: 3 August 2020; Published: 6 August 2020

\begin{abstract}
We present a structural study on late Miocene-early Pliocene out-of-sequence thrusts affecting the southern Apennine orogenic belt. The analyzed structures are exposed in the Campania region (southern Italy). Here, thrusts bound the N-NE side of the carbonate ridges that form the regional mountain backbone. In several outcrops, the Mesozoic carbonates are superposed onto the unconformable wedge-top basin deposits of the upper Miocene Castelvetere Group, providing constraints to the age of the activity of this thrusting event. Moreover, a 4-km-long N-S oriented electrical resistivity tomography profile, carried out along the Caserta mountains, sheds light on the structure of this thrust system in an area where it is not exposed. Further information was carried out from a tunnel excavation that allowed us to study some secondary fault splays. The kinematic analysis of out-of-sequence major and minor structures hosted both in the hanging wall (Apennine Platform carbonates) and footwall (Castelvetere Group deposits and Lagonegro-Molise Basin units) indicates the occurrence of two superposed shortening directions, about E-W and N-S, respectively. We associated these compressive structures to an out-of-sequence thrusting event defined by frontal thrusts verging to the east and lateral ramp thrusts verging to the north and south. We related the out-of-sequence thrusting episode to the positive inversion of inherited normal faults located in the Paleozoic basement. These envelopments thrust upward to crosscut the allochthonous wedge, including, in the western zone of the chain, the upper Miocene wedge-top basin deposits.
\end{abstract}

Keywords: southern Apennines; out-of-sequence thrust; wedge-top basin; electrical resistivity tomography

\section{Introduction}

The study of the kinematics and structural style of thrust sheets, as well as dating their emplacement, is crucial for understanding the tectonic architecture and evolution of orogenic chains. This task can be a challenge when the primary structures are not well exposed, such as the case of the southern Apennines, which has experienced a severe post-orogenic high-angle normal and strike-slip faulting 
starting from the Pleistocene [1-5]. This event produced the deposition at the toe of the mountains of a massive amount of talus during the Early-Middle Pleistocene glacial-interglacial cycles [6-9]. Furthermore, the carbonate ridges, bounding the Campanian Plain (Figure 1a), were locally covered by a considerable amount of pyroclastic deposits (up to tens of meters thick) during the Middle Pleistocene and Holocene activity of the Roccamonfina, Campi Flegrei and Somma-Vesuvius volcanoes (e.g., [10] and references therein), making more and more infrequent the exposure of older structures (i.e., thrust faults).

Recently, many studies have provided temporal constraints to the fault activity in several fold-and-thrust belts worldwide through different geochronological methods. They include isotopic K-Ar and Ar-Ar dating for cataclasites containing silicate minerals (e.g., [11-13]) and U-Th/He, U-Pb dating for the synkinematic carbonate tectonites (e.g., [14,15]). Different authors have applied these methodological approaches also to the study of thrusts in the Apennines (e.g., [16]), and in some cases being able to date multiple reactivations of the thrust faults especially in the case of positive inversion that makes difficult the interpretation of the previous fault kinematics and deformation history (e.g., [17]).

This study focuses on the Campania region in southern Italy (Figure 1a). We have chosen this area because it exposes a large segment of the Apennine orogen [18]. Furthermore, a complete cartography has been recently provided [19] that makes easier the correlations between the different regional structures. Only in recent years, the systematic study of the thrust fault kinematics allowed the full-definition of an out-of-sequence thrusting stage affecting several sectors of the southern Apennines (e.g., $[19,20])$. This tectonic event profoundly changed the original orogenic architecture, made of several thrust sheets, forming a further tectonic imbrication of the Meso-Cenozoic successions (Apennine Platform and Lagonegro-Molise Basin units). This crustal shortening produced a complex regional thrust system with the hanging wall ramp formed by the carbonate ridges of the Marzano-Picentini Mts to the south, up to the Avella-Caserta and Taburno Mts to the north (Figure 1a). The main flat thrust is further exposed in the Campagna tectonic window (Figure 1a) located in the western sector of the chain (e.g., [21]). This study aims to reconstruct the out-of-sequence thrust system geometry and its kinematics through a detailed structural survey and analysis of the principal and secondary structures, and the construction of a 4-km-long geological cross-section. For this purpose, to define the geometry of the thrust system, we used an electrical resistivity tomography survey across the Maddaloni-Durazzano ridge (Figure 1a), and information came out during a tunnel excavation in that area (Mt Aglio access window).

The southern Apennines are a fold-and-thrust belt formed by the superposition of several thrust sheets, including oceanic and continental deep basin to shallow-water successions [18,22-31]. This orogenic chain results from the subduction of the Ligurian oceanic lithosphere beneath the Europe/AlKaPeCa plate, starting from the Paleocene-Eocene and the following Miocene-Middle Pleistocene thrusting and folding affecting the Adria plate (e.g., [18,32] and references therein). The sinking of the oceanic lithosphere triggered the fast eastward migration of the slab hinge (roll-back mechanism, [23]). In the lower Miocene, an accretionary wedge made up of oceanic deep basin sediments developed (Ligurian Accretionary Complex; [24,33,34]). During the Miocene, the Ligurian Accretionary Complex overrode the Adria domain forming a new accretionary prism consisting of thrust sheets of the Apennine Platform (basin to shallow-water) and Lagonegro-Molise Basin (slope to pelagic) successions. From the Messinian to Middle Pleistocene, the allochthonous pile superposed onto the Apulian Platform domain. During the orogenic crustal shortening stage, from lower Miocene to Middle Pleistocene, the orogenic prism was the locus of clastic sedimentation in several wedge-top basins. The unconformable deposits include the uppermost Burdigalian-lower Tortonian Cilento Group, the upper Tortonian-lower Messinian Castelvetere Group (CVTG), the upper Messinian-lowermost Zanclean Altavilla Group (AG), the upper Zanclean Baronia Fm and the Piacentian Sferracavallo Fm [19,35]. At depth, the tectonic pile superposes onto a buried para-autochthon imbricate belt (Figure 1b) consisting of the Apulian Platform succession hosting ramp-dominated thrust faults [36], 
which upward crosscut the allochthonous wedge producing out-of-sequence structures, frequently deforming the upper Miocene-lower Pliocene wedge-top basin deposits [20]. In this work, we studied the segment of the southern Apennines exposed in the Campania region (Figure 1a). The highest mountains include some NW-SE directed ridges made of Meso-Cenozoic carbonates. The tectonic pile is further crosscut by Quaternary high-angle faults with normal to strike-slip kinematics, at places producing large structural depressions filled by marine, transitional and volcanic deposits, such as the Campania Plain (Figure 1a). This study, for the first time, provides a systematic analysis of thrust faults in a vast area of the southern Apennines, which sheds light on the intricate orogenic evolution that characterizes this segment of the circum-Mediterranean Alpine chains.

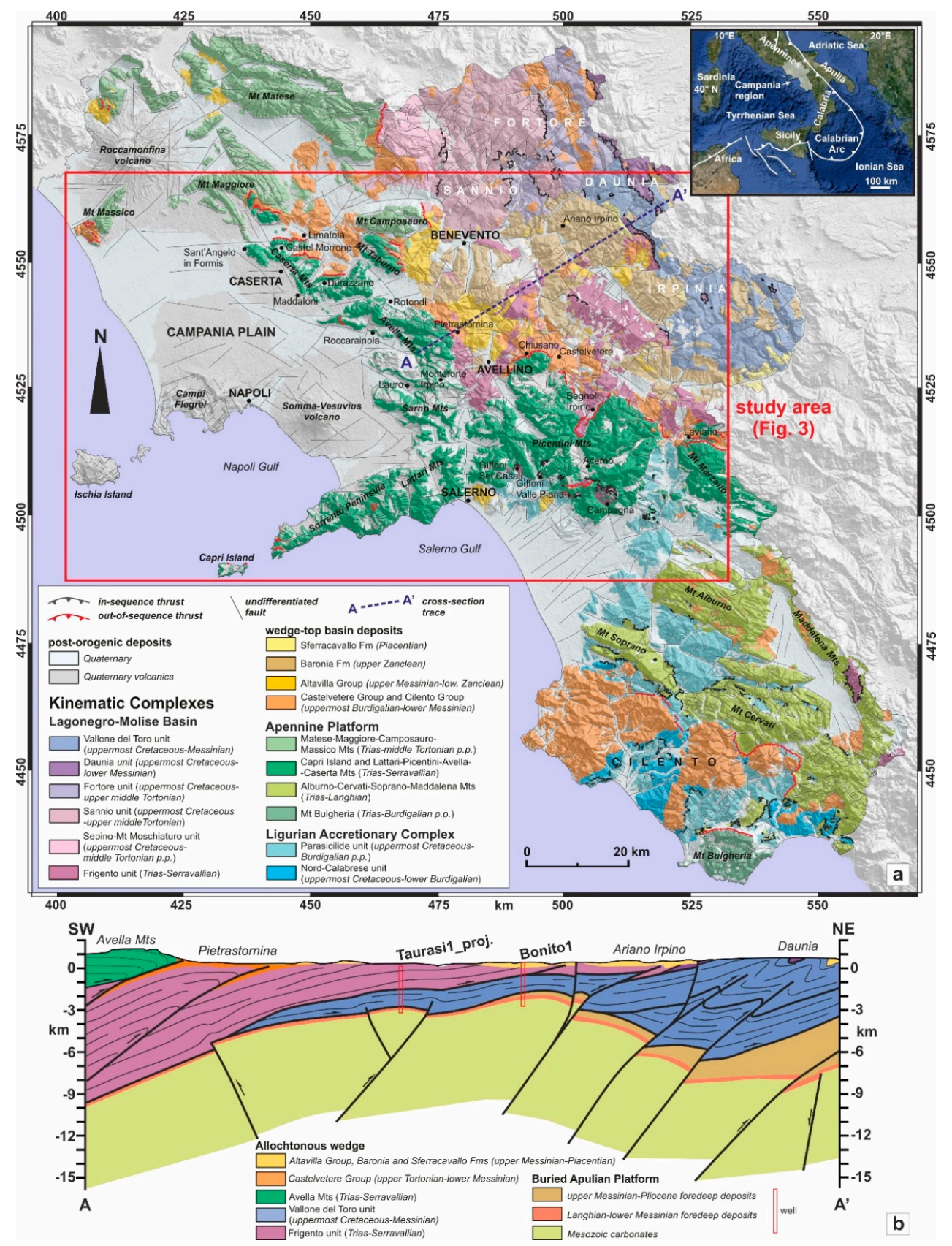

Figure 1. (a) Tectonic scheme of the Campania region (southern Italy), inset map of southern Italy from Google Earth. (b) Cross-section from Avella Mts to the Daunia sector. Modified after [19]. 


\section{Geological Setting}

\section{Regional Stratigraphy}

The sedimentary successions, exposed in the analyzed area (Figures 1a and 2), form different thrust sheets covered by Miocene-Pliocene unconformable wedge-top basin deposits. The tectonic nappes derive from three paleogeographic domains ([18,19,25]; Figure 2): (i) the Ligurian Accretionary Complex; (ii) the Apennine Platform and (iii) the Lagonegro-Molise Basin. The Ligurian Accretionary Complex units (Figure 1a) are represented by the deep-basin Parasicilide succession [25,37], cropping out only in the Sele River Valley, and some limited areas of the Salerno sector. The Parasicilide unit includes uppermost Cretaceous-Eocene p.p. shales (Argille Scagliose Fm), covered by Eocene p.p.-Aquitanian limestones (M.S. Arcangelo Fm), marls and varicolored clays (Argille Varicolori Fm) and finally by Burdigalian foredeep sandstones (Albanella Fm).

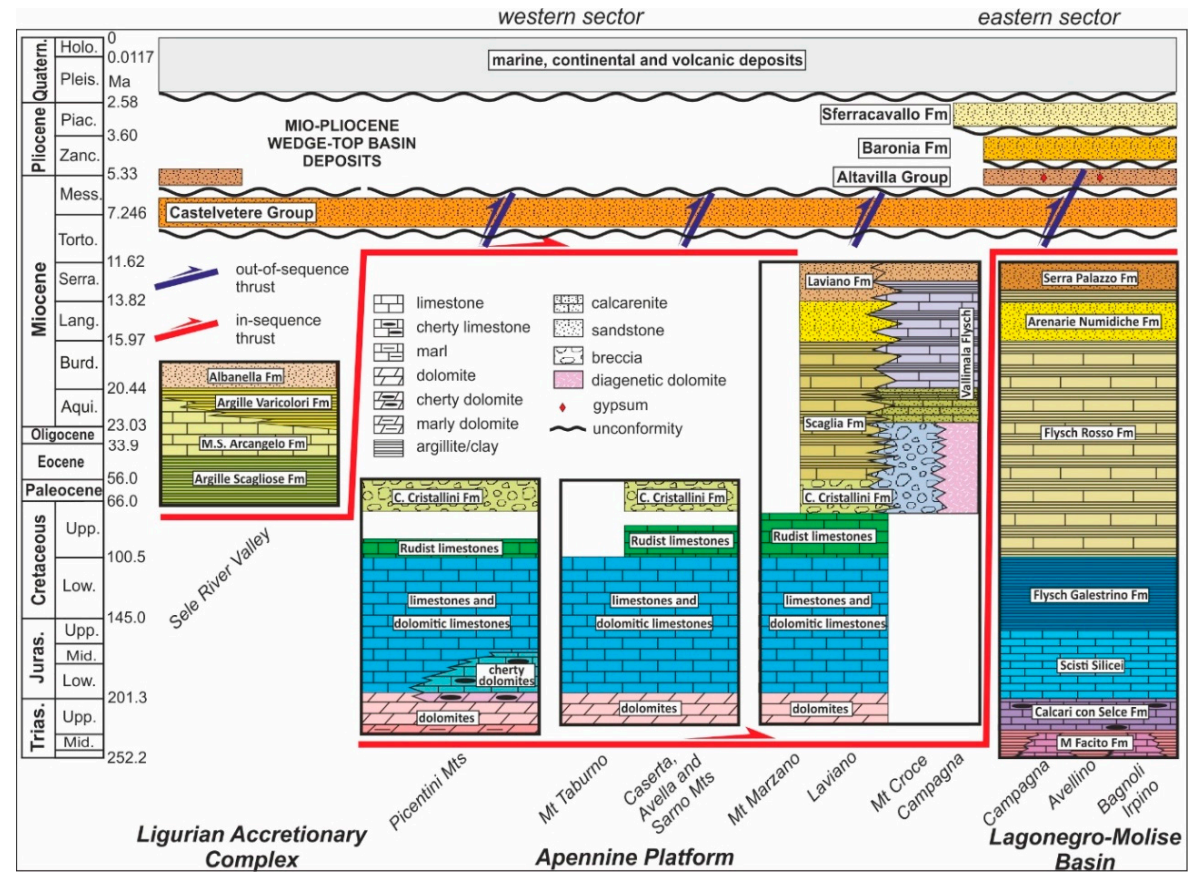

Figure 2. Schematic stratigraphic logs of the analyzed successions.

The Apennine Platform units consist of a dominant carbonate succession ([19,27]; Figure 2) cropping out in the Picentini, Taburno and Caserta Mts. It includes shallow-water rocks made up from the base to the top by Carnian-Hettangian p.p. dolomites and Jurassic-Lower Cretaceous limestones and dolomitic limestones; some lateral heteropies of slope-to-basin cherty carbonates at Picentini Mts occur. The succession continues upward with Upper Cretaceous shallow-water Rudist limestones. At some localities, the Cretaceous shallow-water carbonates pass upward to the uppermost Cretaceous-Paleocene margin recrystallized calcareous breccias (Calcari Cristallini Fm). In the Laviano area, the latter carbonates evolve upward to Eocene-lower Miocene slope-to-basin Scaglia Fm deposits, including cherty limestones, marls and shales, covered by Serravallian foredeep calcarenites and sandstones of Laviano Fm [38]. The Campagna tectonic window exposes a carbonate platform margin succession, known as the Mt Croce unit, consisting of dominant clastic rocks (Vallimala Flysch). Finally, the Lagonegro-Molise Basin units [31,39,40] are represented by the Frigento succession ([18,25]; Figure 2), cropping out eastward of the Apennine Platform ridge and in the Campagna tectonic window [41-43]. The succession includes at the base Anisian-Carnian shallow-water to basin rocks (Monte Facito Fm), evolving upward to Carnian-Lower Cretaceous deep basin deposits (Calcari con Selce, Scisti Silicei and Flysch Galestrino Fms), Upper Cretaceous-Burdigalian slope to basin deposits 
(Flysch Rosso Fm), Langhian sandstones (Flysch Numidico Fm), Serravallian marls and foredeep turbidites (Serra Palazzo Fm).

The upper Tortonian-lower Messinian CVTG is constituted at the base by calcirudites including clasts of Cretaceous-Tertiary limestones, with intercalated layers and lenses of sandstones and residual clays and carbonate clasts upward passing to turbiditic sandstones with intercalations of clays, marls and olistostromes of varicolored clays (Ligurian Accretionary Complex unit) and carbonate olistoliths. These deposits unconformably cover the Ligurian Accretionary Complex, the Apennine Platform and the Lagonegro-Molise Basin units. In the study area, the younger wedge-top basin deposits include the upper Messinian-lowermost Pliocene Altavilla Group, the upper Zanclean Baronia Fm and the Piacenzian Sferracavallo Fm, all characterized by dominant silico- and calciclastic rocks [19].

\section{Methods and Materials}

\subsection{P-B-T Method}

In order to analyze fault slip data, collected in the field, we applied the P-B-T technique [44]. This method furnishes the orientations of the three principal paleostress axes $\sigma 1, \sigma 2$ and $\sigma 3$ (with $\sigma 1>\sigma 2>\sigma 3)$ and the stress ratio $R=(\sigma 2-\sigma 3) /(\sigma 1-\sigma 3)$ [45]. The P-B-T technique provides for every single fault, characterized by well-defined plane attitude, slip orientation and kinematics, the direction of maximum shortening $(\mathrm{P})$, the direction of maximum stretching $(\mathrm{T})$ and the intermediate axis (B), orthogonal to the P-T plane. We used the software TectonicsFP 1.7.8 [46], which allows one to calculate the best-fit angle $(\theta)$, minimizing the sum of all misfit angles between the measured slip direction and the calculated maximum shear stress. In the case of lacking conjugate faults, we used a fixed value of angle $\theta$ equal to $30^{\circ}$ for all fault-slip data.

\subsection{Nannoplankton Content Analysis}

We performed a nannoplankton content analysis on marls and calcareous clay levels of the CVTG deposits sampled in the footwall of the analyzed thrusts to give temporal constraints on the deformational events. We collected 38 samples in the localities of Acerno, Campagna, Castelvetere, Chiusano, Mt Taburno, Maddaloni, Pietra Maula (Lauro), Mt Faggeto (Monteforte Irpino) and Sant'Angelo in Formis (Figure 1a). To obtain optimal results for each type of material, the coccolith specimens were prepared using the centrifugation and simple smear slide techniques, following the procedures described in [47]. We observed the nannoplankton content through the polarized light microscope Zeiss Axioscop equipped with an $\times 100$ oil immersion objective lens. We performed a qualitative evaluation of the assemblages on all the samples, but only 19 of them proved to be fossiliferous, while the other ones resulted barren or very poorly fossiliferous. Dating this material was not a trivial task both because some nannoplankton contents resulted strongly altered by diagenesis, which usually partially or entirely hides the primary morphological characteristics, and because of the intense reworking of specimens. Indeed, many older specimens have been found with very few biostratigraphic markers. However, specimens have been identified at the species level, and biostratigraphic markers have been used for dating.

\subsection{Electrical Resistivity Tomography (ERT)}

A 2D ERT profile is a geophysical prospecting technique that provides an electrical resistivity cross-section of the shallow earth structure until depths of a few tens of hundreds of meters. Among the many applications of the ERT profiling in mining, environmental, engineering and archaeological research [48], it is to emphasize its success in modeling the structural setting of relatively complex geological areas thanks to the capability to define, in terms of electrical resistivity contrasts, the contact between different geological formations and the flexure structure produced by faulting (e.g., [49-55]). The acquired apparent resistivity data were collected by the IRIS SYSCAL Pro SWITCH 96 resistivitymeter in multi-electrode configuration, employing cables with 96 electrodes interspaced 
at $10 \mathrm{~m}$, according to the so-called roll-along technique (e.g., [56,57]), which is commonly used when the measured profile length is greater than the cable length, as for our case study. Specifically, seven roll-along sequences, with overlapping of 48 electrodes between two consecutive rolls, were performed, which allowed us to collect, also thanks to the high 2D coverage offered by the chosen pole-dipole electrode configuration, 27.256 data points along the investigated section and an exploration depth of about $200 \mathrm{~m}$ below the ground level (b.g.1.). All the acquired apparent resistivity values were deployed in a single 2D model, which takes into account the real profile topography, and then processed by the ERTlab ${ }^{\mathrm{TM}}$ software (version 64, Geostudi Astier S.r.1., Livorno, Italy) based on a finite-element inversion algorithm.

\section{Structural Analysis and Data Presentation}

We performed a geological survey in different areas of the southern Apennines, where main out-of-sequence thrusts and related minor structures are exposed. Results are presented starting from the south (Marzano-Picentini Mts) to the north (Caserta Mts).

\subsection{Marzano-Picentini Mts}

We analyzed the Laviano area located along the northern side of the Mt Marzano (Figure 3). Here, the Apennine Platform succession hosts a major thrust that also deforms the wedge-top basin sediments of the CVTG. To the north of the analyzed area, the Lagonegro-Molise Basin unit is exposed, covered by the CVTG. Several secondary structures are associated with the main thrust, such as minor thrust faults within the Serravallian calcarenites (Laviano Fm; Figure 4a), several S-C structures (Figure 4b) and pre-buckle thrusts marked by the cherty layers (Figure 4c) within the Paleogene-lower Miocene Scaglia Fm (Figure 2). In the footwall of the main thrust, the CVTG deposits cover the carbonates, filling graben where the former normal faults are cut by the younger thrust faults (Figure $4 \mathrm{~d}, \mathrm{e}$ ). The plot of thrust faults (Figure 5a) suggests a prevalence of planes moderately dipping to SSW, and the related PBT diagram indicates an NNE-SSW shortening.

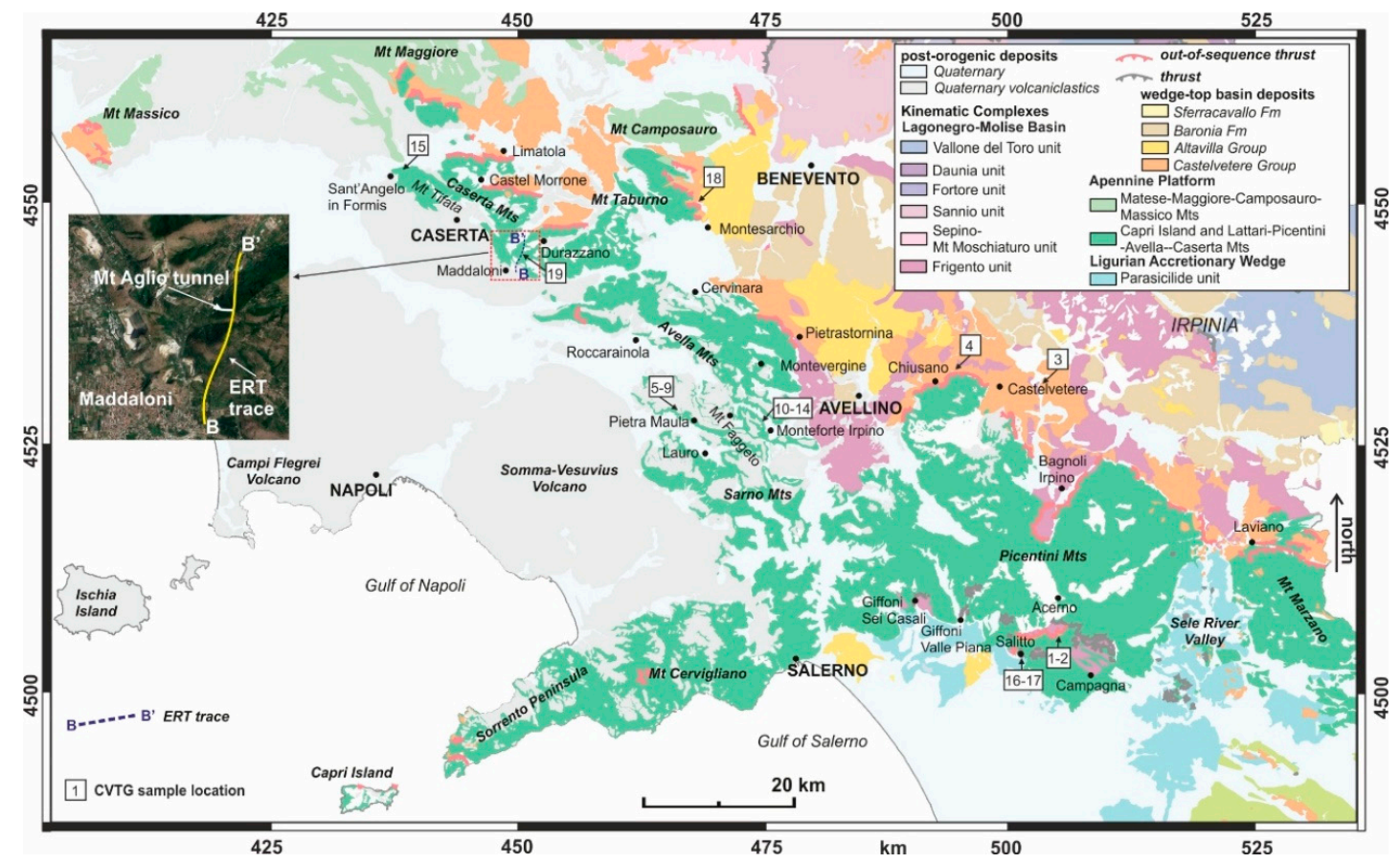

Figure 3. Tectonic map of the study area showing the analyzed sites and the trace of the electrical resistivity tomography (ERT) profile and tunnel excavation. 

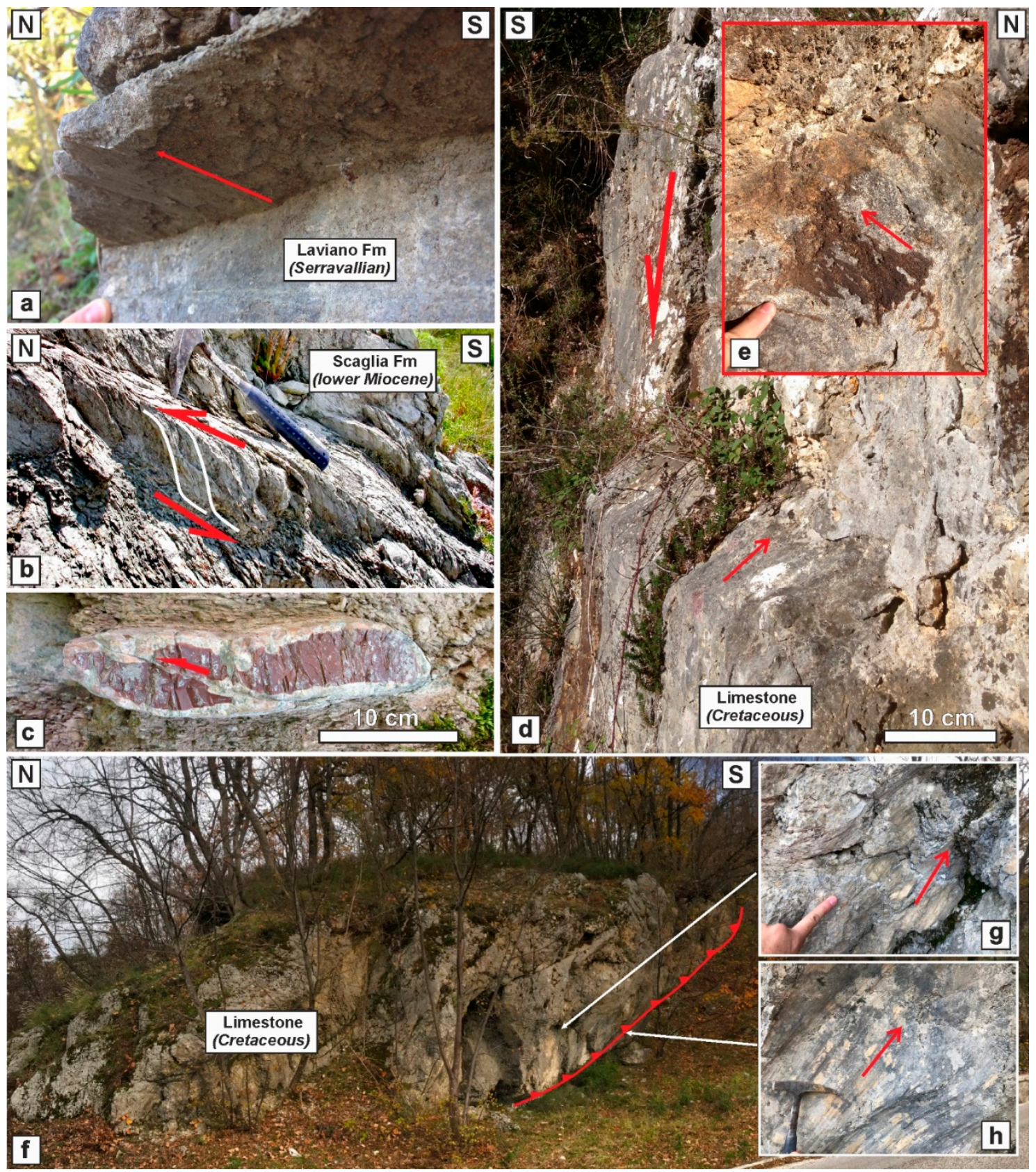

Figure 4. Laviano: (a) thrust fault in calcarenites of the Laviano Fm.; (b) S-C structures associated to a north-verging thrust within the gray Scaglia Fm; (c) pre-buckle thrust in red chert within the Scaglia Rossa Fm; (d,e): normal fault plane crosscut by north-verging thrust faults. Bagnoli Irpino: (f) back-thrust within the Cretaceous succession; $(\mathbf{g}, \mathbf{h})$ striations and steps.

The mountain area surrounded by the Laviano, Avellino, Salerno and Campagna towns (Figure 3), includes the carbonate ridge of the Picentini Mts, facing northward to the Irpinia area, dominated by the Frigento unit (Lagonegro-Molise Basin) covered by the wedge-top basin deposits of CVTG, Baronia and Sferracavallo Fms. The Picentini Mts confine to the east with the Sele River Valley, where the Ligurian Accretionary Complex is widely exposed [37]. Here, the out-of-sequence thrust between the carbonates and Frigento unit, with the interposition of the CVTG, is exposed only in a few localities. In the areas where the main thrust is hidden, several secondary structures allowed us to reconstruct the geometry and kinematics, such as the Bagnoli Irpino area (Figure 3). Here, a few deformation structures are exposed; amongst others, a good example is the back-thrust within the Mesozoic limestones 
(Figure 4f), accompanied by several secondary slickenside planes with striations and steps (Figure 4g,h). These structures indicate a vergence to the south (Figure 5b). In the Chiusano-Castelvetere area (Figure 3), the Upper Cretaceous limestones tectonically cover the CVTG deposits through a flat-lying ramp (Figure 6a). The frontal thrust form an anticline ramp evidenced by the high-angle bedding of carbonates and overlying CVTG deposits. An instructive example is in the quarry located close to the Chiusano village; here, the almost vertical strata show also parasitic folds (Figure 6b). In this case, the well-cemented Pleistocene slope talus preserved these structures, presently exposed by the digging activity. In a dismissed quarry, a back-thrust verging to the south occurs within the carbonates with a drag fold in the footwall (Figure 6c). Only in one locality, close to the Castelvetere village (Figure 3), the superposition of carbonates onto clays and sandstones of Castelvetere is exposed (Figure 6d,e). The siliciclastic rocks form lenses within a cataclasite, subsequently cut by normal faults (Figure 6d). The measured fault planes (Figure 5c) dip to the north and the east; however, the PBT diagram indicates an E-W shortening.

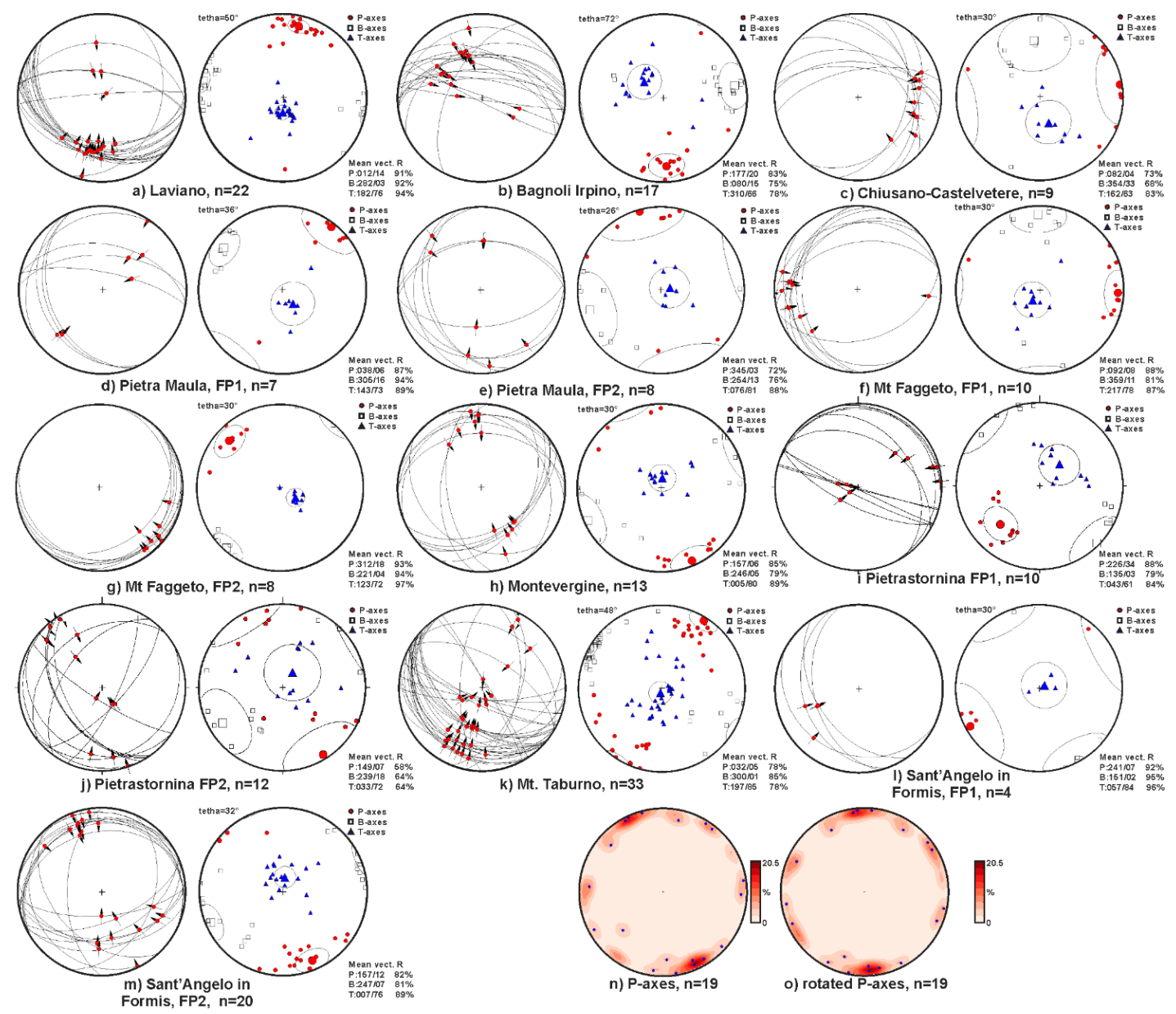

Figure 5. Stereographic projections of (a-m) faults and corresponding PBT plots; (n) T-axes; (o) T-axes rotated $20^{\circ}$ counterclockwise. 

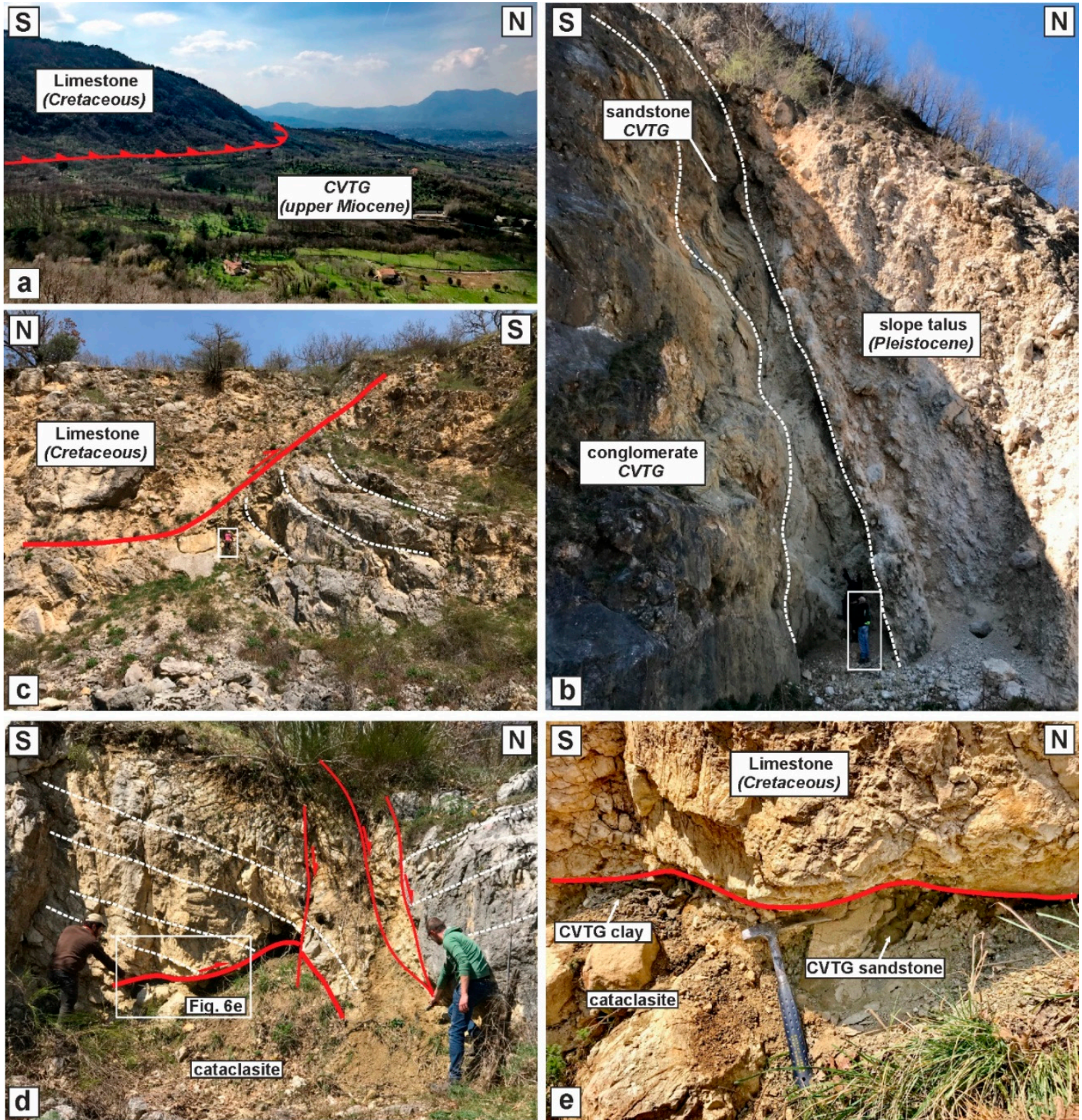

Figure 6. Chiusano area: (a) panoramic view of the frontal thrust; (b) highly dipping forelimb of the hanging wall anticline associated to the frontal thrust formed by Upper Cretaceous carbonates covered by beds of Castelvetere Group (CVTG) conglomerates and sandstones; the succession is covered by the Middle Pleistocene slope talus (Belvedere quarry); (c) back-thrust within the Upper Cretaceous limestones with an associated footwall syncline. Castelvetere area: (d) the main thrust crosscut by late normal faults; (e) particulars of the cataclasite in the footwall made of lenses of clays and sandstones of the CVTG.

\subsection{Avella and Taburno Mts}

In this area, the Apennine Platform and Lagonegro-Molise Basin units crop out, unconformably covered by CVTG, Altavilla Group and Baronia Fm. Along the E-W ridge of Roccarainola (Figure 3), [58] reported the occurrence of a major thrust. The authors indicate an NNW tectonic vergence of the thrust that juxtaposes the Jurassic carbonates on the Cretaceous rocks with an associated hanging wall overturned anticline. In this work, we analyzed further outcrops, including the Lauro, Monteforte and Montevergine areas (Figure 3). Along the road connecting Lauro with the town of Avellino, deposits of the lower part of the CVTG are exposed, covering the Upper Cretaceous carbonates. 
At Pietra Maula (north of Lauro) and Mt Faggeto (northwest of Monteforte Irpino), a $20 \mathrm{~m}$ thick CVTG succession crops out (Figure 3) consisting of calcareous conglomerates with lenses of sandstones and red and grey clays (Figure 7a-d). Clasts are mainly made of the Eocene Trentinara Fm (e.g., [19]), not exposed in the analyzed area. The succession hosts two sets of thrusts and folds. In the Pietra Maula outcrop, the main thrust superposes the Upper Cretaceous carbonates onto the upper Miocene conglomerates, sandstones and clays (Figure 7a). Minor thrust faults deform the clay lenses (Figure 7a), in particular, it is common to find along the same fault plane two sets of slickenside striations and steps (Figure 7b) indicating an early ENE-WSW shortening, with associated folds especially in the clay and sand lenses, and a later NNW-SSE shortening. Two sets of thrust faults are also observed in Mt Faggeto. However, the NW-verging thrust is the best-developed (Figure 7e). At Pietra Maula, fault planes of the first out-of-sequence deformation (Figure $5 \mathrm{~d}$ ) form a conjugate system with a statistical NE-SW shortening direction, whereas the structures related to the second deformation stage (Figure 5e) suggest a NNW-SSE shortening. At Mt Faggeto, the thrust faults are W-dipping with an E-W shortening direction for the first deformation stage (Figure 5f), whereas the fault planes, related to the second stage, are gently dipping to SE, indicating an NW-SE shortening (Figure 5g). On the top of the Montevergine mountain, the Apennine Platform Jurassic carbonates overthrust the CVTG (Figure 7f), the latter made of calcareous conglomerates with a sandy matrix. Only in the upper part of these clastic deposits, clasts are made of crystalline rocks. Thrusts and related folds occur in the Apennine Platform Jurassic succession (Figure $7 \mathrm{~g}$ ) as well as the presence of pressure solution planes orthogonal to the bedding (Figure 7h). Thrust faults form a conjugate system, of which the PBT diagram provides an NNW-SSE shortening direction (Figure $5 \mathrm{~h}$ ). The carbonate ridge from Montevergine to Cervinara (Figure 3) is defined by Apennine Platform Cretaceous limestones covered by the CVTG deposits forming an anticline ramp with high-angle strata along the northern side. The best exposure is in the Pietrastornina area (Figure 3), where CVTG beds are steep and locally overturned (Figure 8a,c). In a few localities, the thrust is exposed, indicating a double vergence, with shales and sandstones in the footwall (Figure 8b). Generally, the CVTG conglomerate shows indented clasts (Figure 8d). In the footwall of the main thrust, the Frigento succession and the overlying CVTG deposits are deformed by folds and thrusts. Remarkable examples are the ramp anticlines within the slope carbonates of the Flysch Rosso Fm (Frigento unit) cropping out in different places such as that exposed in the quarry north of Pietrastornina (Figure 8e). Here, the vertical beds of the Flysch Rosso Fm and CVTG deposits are cut by sub-horizontal thrusts with small displacements and associated drag folds in the footwall (Figure 8e). Measured thrust faults mark two shortening directions: NE-SW and NW-SE (Figure 5i,j). Another place to observe the major structure is at the toe of Triassic-Jurassic carbonates of the Mt Taburno located north of the Avella Mts (Figure 3). Along the NE-side of this mountain, the main thrust crops out. It is defined by a flat-lying fault (Figure 8g) with highly deformed clays and sandstones in the footwall (Figure $8 \mathrm{~h}$ ). Striations and steps indicate a N vergence. Several secondary thrust faults are present (Figure 8g). Such as the previous areas, here the main thrust is cut by younger normal faults. Associated with this thrust, some folds in Flysch Rosso Fm in the footwall occur, the largest is a thigh overturned fold verging to the north (Figure $8 \mathrm{f}$ ). Poles to fold limbs indicate a theoretical fold axis of 302/24 (Figure 8f). Thrust planes moderately dip to SE, and the PBT diagram suggests an NE-SW shortening direction (Figure $5 \mathrm{k}$ ).

\subsection{Caserta Mts}

The Caserta Mts (Figure 3) are formed by three E-W trending carbonate ridges of Maddaloni, Castel Morrone and Limatola Mts, and the NW-SE trending Mt Tifata (Sant'Angelo in Formis). A few are the sites in the Limatola ridge where secondary thrusts are exposed. The best outcrop is located along the road connecting the Castel Morrone and Limatola towns (Figure 3). Here, a major back-thrust occurs (Figure 9a), which brings the Apennine Platform Jurassic limestones to overthrust the CVTG deposits. Minor thrust faults occur, suggesting an N-S shortening. The area of Sant'Angelo in Formis was the subject of a few studies in the last century (e.g., [59,60]). Reference [60] describes several thrust 
faults between Mesozoic Apennine Platform carbonates (hanging wall) and CVTG in the footwall. We have not found the thrusts described by these authors. However, we observed several minor structures, such as mesoscale thrusts and related folds. Two sets of secondary thrusts are present, the first furnishes an ENE-WSW shortening direction (Figure 5l), whereas the second set indicates an NNW-SSE shortening (Figure 5m).
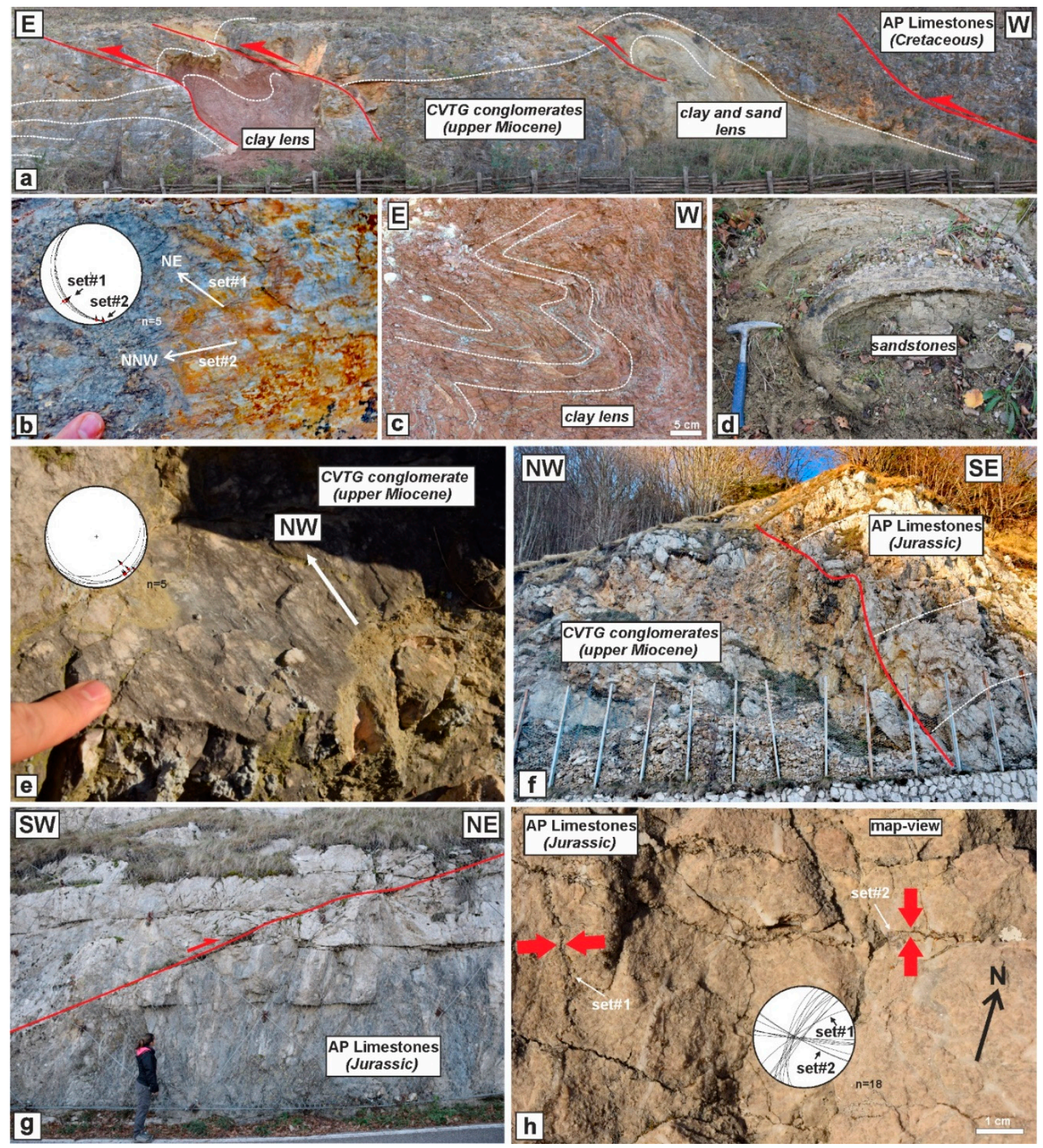

Figure 7. Pietra Maula: (a) imbricate fan of thrust sheets superposing Apennine Platform (AP) limestones onto CVTG conglomerates, sandstones and clays; (b) thrust fault plane showing two sets of slickenside striations and steps; (c) folds in CVTG clays; (d) fold in the CVTG sandstones. (e) Thrust plane showing striations and steps indicating an N vergence (Mt Faggeto). Montevergine: (g high-angle thrust of AP Jurassic limestones onto CVTG; (h) two orthogonal stylolite sets in AP Jurassic oolitic limestones. 

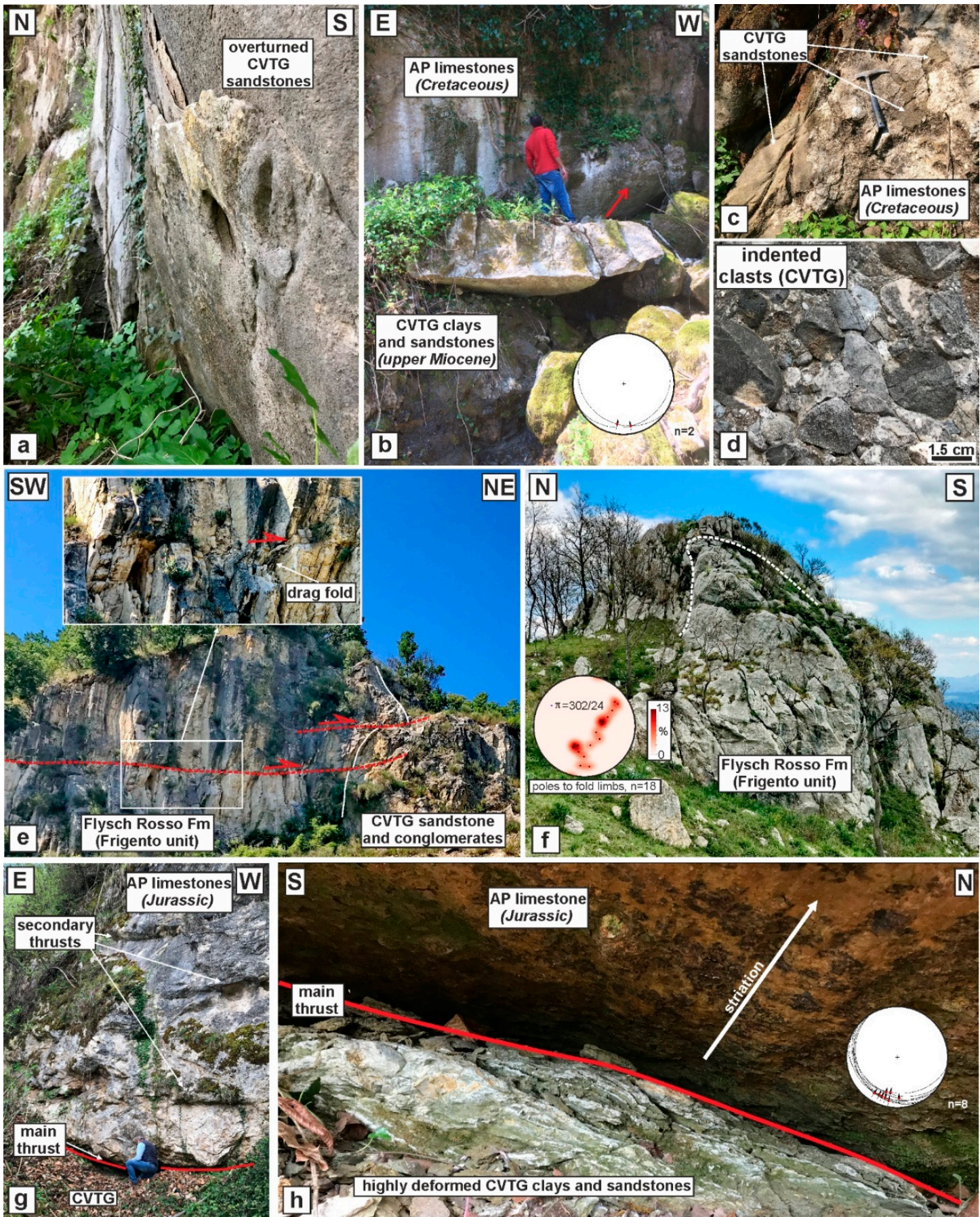

Figure 8. Pietrastornina: (a) overturned CVTG beds; (b) main thrust fault of Apennine Plattform (AP) Cretaceous limestones onto shales and sandstones of CVTG; (c) CVTG sandstone covering AP Cretaceous limestones; (d) indented calcareous clasts in CVTG; (e) vertical beds of Flysch Rosso Fm crosscut by a sub-horizontal thrust verging to NE with associated drag folds in the footwall. Mt Taburno: (f) overturned fold in Flysch Rosso Fm verging to the north; (g,h) the main thrust between AP Jurassic carbonates onto highly deformed clays of CVTG. 

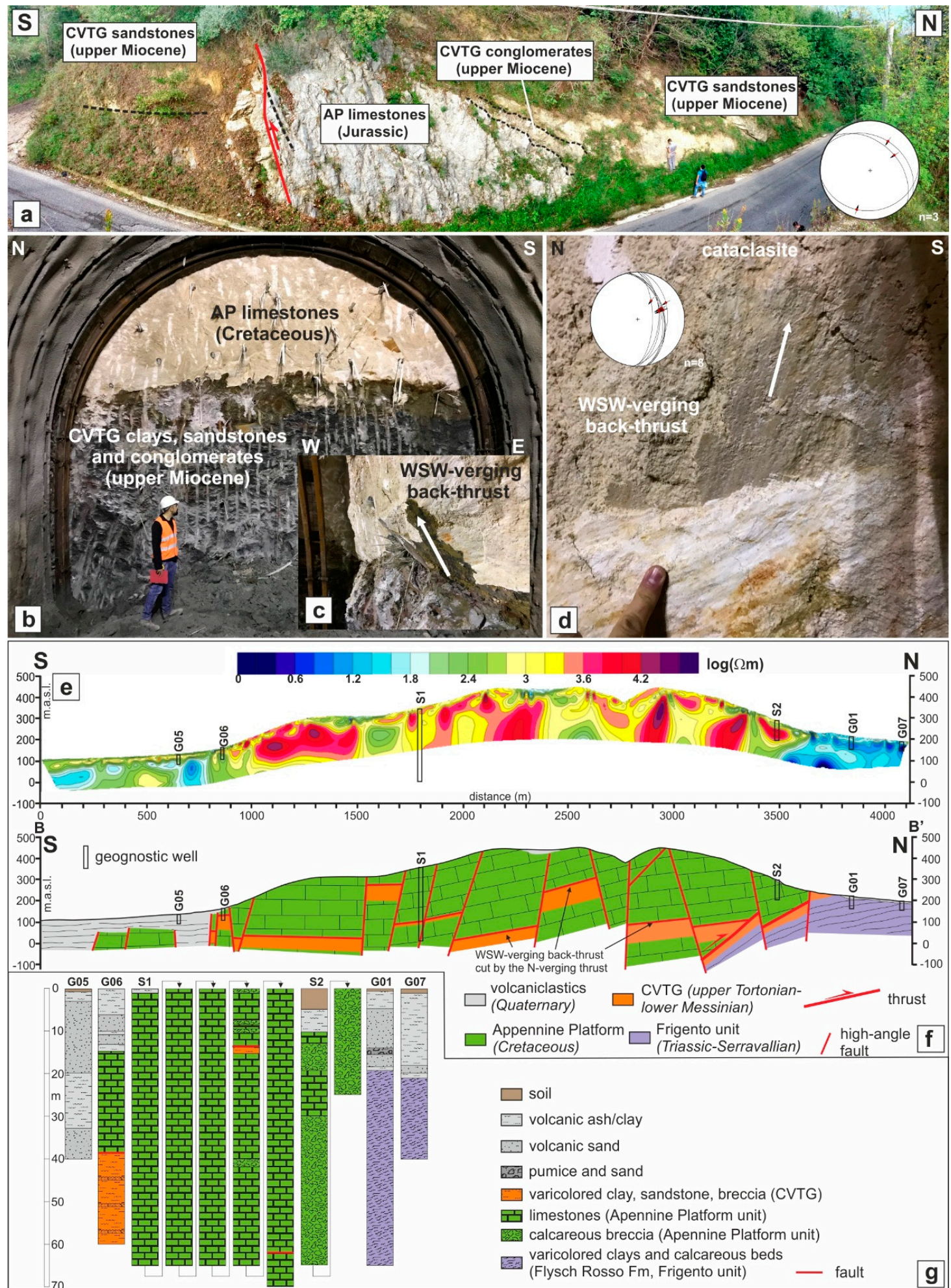

volcaniclastics $\square$ CVTG (upper Tortonian-

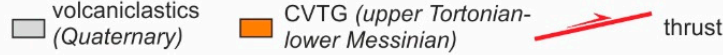

$\square \begin{aligned} & \text { Appennine Platform } \\ & \text { (Cretaceous) }\end{aligned} \begin{aligned} & \text { Frigento unit } \\ & \text { (Triassic-Serravallian) } \quad / \text { high-angle } \\ & \text { fault }\end{aligned}$

$\square$ soil

volcanic ash/clay

$\therefore$ volcanic sand

믐 pumice and sand

varicolored clay, sandstone, breccia (CVTG)

四 limestones (Apennine Platform unit)

㡠 calcareous breccia (Apennine Platform unit)

varicolored clays and calcareous beds (Flysch Rosso Fm, Frigento unit) __ fault

Figure 9. (a) Back-thrust of Apennine Platform (AP) Jurassic limestones onto CVTG sandstones (Limatola). Maddaloni Tunnel: (b) excavation front showing the tectonic superposition of the AP Cretaceous carbonates onto the CVTG; (c) particulars of the back-thrust plane; (d) slickenside striations and stereographic projections of thrust faults. (e) ERT profile; (f) cross-section; (g) well logs. 


\subsubsection{Maddaloni Carbonate Ridge}

The northern slope of the Maddaloni ridge is E-W oriented (Figure 3). Here, the carbonate ridge is bounded by normal faults that hide the main thrust. To investigate the tectonic architecture in depth, we used an ERT profile $4 \mathrm{~km}$ long, and N-S directed, crosscutting the western side of the ridge, from the Maddaloni town to the north (Figure 3). Furthermore, we followed the excavation of an E-W directed tunnel within the carbonate succession orthogonal to the ERT profile (Figure 3). The structural survey performed on the excavation fronts furnished useful information about the geometry and kinematics of thrust faults hosted in the Apennine Platform Meso-Cenozoic succession. The best structure observed is defined by the superposition of Cretaceous carbonates onto CVTG varicolored clays, sandstones and conglomerates (Figure 9b). The footwall is highly deformed with well-marked foliation and some overturned folds. Along the thrust plane dipping to west, we observed striations and steps (Figure 9c,d) indicating a vergence to WSW. Finally, we reconstructed a geological cross-section (B-B'; Figure 9f), integrating data from some geognostic wells (Figure 9g), the ERT profile (Figure 9e) and information gathered in the tunnel. It is interesting to note that in the well G06 (Figure 9g), the Cretaceous limestones tectonically cover the CVTG clays. Further, in the well S1, a cataclasite with a varicolored clayey matrix is present at $-275 \mathrm{~m}$ below the field surface.

\section{ERT-Cross Section}

The ERT profile used to reconstruct the architecture of the Maddaloni ridge fault zone is indicated in Figure 3 as B-B'. It extends approximately S-N in a straight line for $4100 \mathrm{~m}$. The inverted resistivity section (Figure 9e) was obtained for a root mean square misfit error lower than $10 \%$ to the field data. The resistivity model shows a generally resistive pattern abruptly broken by two prominent conductive zones at the ends of the profile. The architecture of the resistive zone appears rather complex: sectors characterized by resistivity values of a few thousand of $\Omega \mathrm{m}$ (shades of yellow color in Figure 9e), which are locally interrupted by very high-resistivity nuclei $\left(>10^{4} \Omega \mathrm{m}\right.$, shades of red color in Figure $\left.9 \mathrm{e}\right)$, overtop areas with resistivities of the order of some hundreds of $\Omega \mathrm{m}$ (deep green color zones in Figure 9e). Both the amplitudes and inhomogeneous distribution of the observed high-resistivity values (yellow and red sectors in Figure 9e) are consistent with strongly fractured calcareous rocks, likely interested by karstic phenomena. Different water contents along fault/fracture systems and/or degraded portions of the carbonate structure can, therefore, justify this wide range in the observed resistivity variations.

Conversely, the deep relatively conductive zones can well describe, both for the measured resistivity values and for their shape and in-depth position, clay lenses, sandstones and conglomerates, such as those highlighted by the tunnel excavation (Figure 9c). Finally, the abrupt lowering of the resistivity values observed at the two ends of the ERT profile can instead be attributed to the contact of the calcareous formation with lithologically different formations. In particular, we note that the resistivity values observed in the southern edge of the profile are compatible with pyroclastic deposits, while the very low resistivity values in the northern part $\left(<10^{2} \Omega \mathrm{m}\right.$, shades of blue color in Figure 9e) well correlate with clayey materials characterized by different degrees of compaction.

In order to validate the interpretative hypotheses coming from the ERT prospection, we have compared the modeled cross-section with available geological evidence from geognostic surveys located along the ERT profile (Figure 9e). In particular, the S1 and S2 stratigraphic logs (Figure 9g) show a very thin layer of topsoil followed by altered/degraded limestone from weakly to strongly fractured, locally rather vacuolar. The other well, drilling a calcareous succession, is G06 (Figure 9g). The stratigraphy shows an upper interval of tectonized limestones overlying highly deformed clays similar to that observed in the tunnel excavation that we ascribed to the CVTG. Completely different geological sequences, instead, come from the three geognostic wells placed at both ends of the ERT cross-section. The G05 stratigraphic column (Figure 9g) is constituted down to the maximum exploration depth by horizons of silts (or sandy-silts), which alternate with levels of sands (or silty-sands) from fine to coarse grain size with the inclusion of weakly cemented pyroclasts. 
Conversely, the stratigraphy provided by the G01 and G07 wells (Figure 9g) shows an alternation of pyroclastic layers that differ in size (clay, silts, sands and gravel) and saturation degree only for the shallowest portion of the investigated subsurface. Starting at a depth of about $20 \mathrm{~m} \mathrm{b.g.l.,} \mathrm{varicolored}$ shales of the Frigento unit are found, which are characterized by the lowest values of the electrical resistivity observed along the whole profile. The ERT model, combined with geological field data, has been used to reconstruct the cross-section in Figure 9f, where high-angle faults are recognized by sharp decreases in resistivity due to the increase in permeability values associated with a higher density of fractures. The sharpest resistivity contrast in the northernmost part of the profile well marks the main thrust fault.

\section{Nannoplankton Content Analysis}

The nannoplankton analysis carried out on the CVTG samples (Table 1) indicates mainly an upper Miocene age for the fossiliferous samples, although they are affected by intense reworking. The samples from CVTG5 to CVTG14 collected at Pietra Maula (Lauro) and Mt Faggeto (Monteforte Irpino) are characterized by the presence of biostratigraphic markers as Discoaster brouweri (Figure 10a), D. surculus, D. variabilis (Figure 10b), Helicosphaera wallichii (Figure 10c) and Sphaenolithus abies. In the samples CVTG1-2 and CVTG16-17 collected in the areas of Acerno and Salitto, we found the markers Discoaster variabilis, Helicospaera wallichii and Sphaenolithus abies. The samples CVTG3-4 collected in the Castelvetere and Chiusano localities contain the markers Discoaster brouweri, D. variabilis and Sphaenolithus abies (Figure 10d) in association with other specimens as Reticulofenestra pseudoumbilicus (Figure 10e; Table 1). CVTG18 sampled in the Mt Taburno area revealed the presence of the markers Discoaster loeblichii (Figure 10f) and D. variabilis. We found the markers Helicospaera wallichii, and Sphaenolithus abies in the sample CVTG19 collected in the Maddaloni tunnel. Finally, the sample CVT15 collected at Sant'Angelo in Formis did not reveal the presence of any biostratigraphic markers. However, we found an association of specimens that is comparable with most of the other samples. Based on the first occurrence datum of these markers found in the CVTG, we can consider these deposits as no older than the upper Tortonian. Due to the occurrence of the markers D. loeblichii and $D$. surculus, we can constrain these deposits as ranging from the lower part of the nannofossil zone NN11 of [61], which corresponds to the base of CN9A of [62] or CNM16 of [63], to the upper part of the NN11 of [61], corresponding to CN9B of [62] or CNM18 of [63]. We cannot define the last occurrence datum for all of the formation due to the intense reworking of the specimens and also because not all the samples contain markers as D. loeblichii with a very narrow time range of distribution (e.g., for $\mathrm{Mt}$ Taburno area). However, if we consider that all these deposits are coeval and belong to the CVTG, their age can be constrained to the upper Tortonian-lower Messinian. This result also agrees with the age of CVTG recently dated in Mt Massico and Sorrento Peninsula $([20,64])$ and with the literature on the wedge-top basin deposits of Castelvetere Fm [18,25,65,66]. 
Table 1. Summary of biostratigraphic data (calcareous nannofossils). X: occurrence of specimen; R: reworked specimen; M: marker specimen.

\begin{tabular}{|c|c|c|c|c|c|c|c|c|c|c|c|c|c|c|c|c|c|c|c|}
\hline CVTG SAMPLE & 1 & 2 & 3 & 4 & 5 & 6 & 7 & 8 & 9 & 10 & 11 & 12 & 13 & 14 & 15 & 16 & 17 & 18 & 19 \\
\hline Braarudosphaera bigelowii & & & & $x$ & & & & & $x$ & $x$ & & & $x$ & & & & & & \\
\hline Carinaster sp. & & & & & & & & & & & & & $x$ & & & & & & \\
\hline Calcidiscus leptoporus & & & $\mathrm{X}$ & $x$ & & & & & & & & $x$ & $X$ & $\mathrm{X}$ & $x$ & & & $\mathrm{X}$ & $x$ \\
\hline Calcidiscus macintyrei & & & $x$ & $x$ & & & & & & & & & & & & & & $x$ & \\
\hline Coccolithus formosus & & & & & $\mathrm{R}$ & $\mathrm{R}$ & & & $\mathrm{R}$ & & & & & & & $\mathrm{R}$ & & & $\mathrm{R}$ \\
\hline Coccolithus pelagicus & $x$ & $x$ & $x$ & $X$ & & & $x$ & $\mathrm{X}$ & $X$ & $X$ & $x$ & $x$ & $\mathrm{X}$ & $x$ & $X$ & $X$ & $X$ & $x$ & $x$ \\
\hline Coccolithus miopelagicus & & & & & & & & & & & & & $\mathrm{R}$ & & & & & & \\
\hline Coccolithus tenuiforatus & & & & $\mathrm{X}$ & & & & & & & & & & & & & & & \\
\hline Cruciplacolithus sp. & & & & & & & & & & & & $\mathrm{X}$ & & $x$ & & & & & \\
\hline Cyclicargolithus abisectus & & & & & & & & & $\mathrm{R}$ & & & & & & & & & & \\
\hline Cyclicargolithus floridanus & $\mathrm{R}$ & $\mathrm{R}$ & & $\mathrm{R}$ & & & $\mathrm{R}$ & $\mathrm{R}$ & $\mathrm{R}$ & & $\mathrm{R}$ & $\mathrm{R}$ & $\mathrm{R}$ & & & $\mathrm{R}$ & & & \\
\hline Discoaster barbadiensis & & & & & & & & & $\mathrm{R}$ & $\mathrm{R}$ & & & & & & & & & \\
\hline Discoaster brouweri & & & & $\mathbf{M}$ & & & & & & & & & $\mathbf{M}$ & & & & & & \\
\hline Discoaster deflandrei & & & & & & & & & $\mathrm{R}$ & & & & & & & & & & \\
\hline Discoaster druggii & & & & & & & & & & $\mathrm{R}$ & & & & & & & & & \\
\hline Discoaster loeblichii & & & & & & & & & & & & & & & & & & $\mathbf{M}$ & \\
\hline Discoaster multiradiatus & & & & $\mathrm{R}$ & $\mathrm{R}$ & & & & & & & & & & & & & & \\
\hline Discoaster saipanensis & & & & & & $\mathrm{R}$ & & & $\mathrm{R}$ & & & & & & & & $\mathrm{R}$ & & \\
\hline Discoaster salisburgensis & & & & & & & & & & $\mathrm{R}$ & & & & & & & & & \\
\hline Discoaster surculus & & & & & & & & & & & & & $\mathbf{M}$ & & & & & & \\
\hline Diascoaster variabilis & & & & $\mathbf{M}$ & & & & & & & & & $\mathbf{M}$ & & & & $\mathbf{M}$ & $\mathbf{M}$ & \\
\hline Helicosphaera carteri & $\mathrm{X}$ & $\mathrm{X}$ & & & & & & & $x$ & & $X$ & $X$ & $X$ & & $x$ & & & & \\
\hline Helicosphaera recta & & $\mathrm{R}$ & & & & & & & & & & & & & & & & & \\
\hline Helicosphaera walbersdorfensis & & & & & & & & & $\mathrm{R}$ & & & & & & & & & & \\
\hline Helicosphaera wallichii & & $\mathbf{M}$ & & & & & & & $\mathbf{M}$ & & & & & & & & & & $\mathbf{M}$ \\
\hline Microrhabdulus decoratus & & & & & & & & & $\mathrm{R}$ & & & & & & & & & & \\
\hline Nannotetrina sp. & $\mathrm{R}$ & & & & & & & & & & & $\mathrm{R}$ & $\mathrm{R}$ & & & $\mathrm{R}$ & & & \\
\hline Pontosphaera discopora & & & & & & & & & & & & & $x$ & & & & & & $x$ \\
\hline Pontosphaera multipora & & & & & & & & & & & & & $x$ & & & & & & $X$ \\
\hline Reticulofenestra bisecta & $\mathrm{R}$ & $\mathrm{R}$ & & $\mathrm{R}$ & $\mathrm{R}$ & & $\mathrm{R}$ & $\mathrm{R}$ & $\mathrm{R}$ & & $\mathrm{R}$ & $\mathrm{R}$ & & & $\mathrm{R}$ & & & & \\
\hline Reticulofenestra dictyoda & & & & & & & & & $\mathrm{R}$ & & & & & & & & & & \\
\hline Reticulofenestra haqii & & & & & & & & & & & & & $x$ & & & & & & \\
\hline Reticulofenestra minuta & & & & $x$ & & & & & & & & $X$ & $x$ & & & $x$ & $X$ & $X$ & \\
\hline $\begin{array}{l}\text { Reticulofenestra } \\
\text { pseudoumbilicus }\end{array}$ & $x$ & $x$ & & $x$ & & & & & $x$ & & & $x$ & $x$ & $x$ & & $x$ & $x$ & & \\
\hline Sphenolithus abies & & $\mathbf{M}$ & $\mathbf{M}$ & $\mathbf{M}$ & & & & $\mathbf{M}$ & & & & & & & & & $\mathbf{M}$ & & M \\
\hline Sphenolithus ciperoensis & & & & & & & & & & $\mathrm{R}$ & & & & & & & & & \\
\hline Sphenolithus conicus & & & & $\mathrm{R}$ & & & & $\mathrm{R}$ & & & & & & & & $\mathrm{R}$ & & & \\
\hline Sphenolithus delphix & & & & & & & & & $\mathrm{R}$ & & & & & & & & & & \\
\hline Sphenolithus dissimilis & & $\mathrm{R}$ & & & & & & & & & & & & & & & & & \\
\hline Sphenolithus heteromorphus & & & & & & & & & $\mathrm{R}$ & & & & & & & $\mathrm{R}$ & $\mathrm{R}$ & & \\
\hline Sphenolithus moriformis & & $x$ & & $x$ & & & $x$ & $\mathrm{X}$ & $\mathrm{X}$ & & & $x$ & & $\mathrm{X}$ & $x$ & $x$ & $x$ & & $x$ \\
\hline Sphenolithus neoabies & & & & & & & & & & & & & $x$ & & & & & & \\
\hline Sphenolithus radians & & & & $\mathrm{R}$ & & & & $\mathrm{R}$ & $\mathrm{R}$ & & & $\mathrm{R}$ & & & & & & & \\
\hline Sphenolithus procerus & & & & $\mathrm{R}$ & & & & $\mathrm{R}$ & & & & & & & & & & & \\
\hline Transversopontis sp. & & & & & & & & & & $\mathrm{R}$ & & & & & & & & & \\
\hline Watznaueria barnese & & & & & & & & & $\mathrm{R}$ & $\mathrm{R}$ & & & & & & & & & \\
\hline Zygrhablithus bijugatus & $\mathrm{R}$ & & $\mathrm{R}$ & & & & & & $\mathrm{R}$ & & & & $\mathrm{R}$ & & & $\mathrm{R}$ & & & \\
\hline
\end{tabular}

UTM (33T, WGS84) coordinates (meter) of the listed samples: CVTG1 and CVTG2 (Acerno): 503794E, 4505896N; CVTG3 (Castelvetere): 503508E, 4530468N; CVTG4 (Chiusano): 494276E, 4532154N; CVTG5 to CVTG9 (Pietra Maula): 469301E, 4527138 N; CVTG10 to CVTG14 (Monteforte Irpino): 33T 472491E, 4527607N; CVTG15 (Sant'Angelo in Formis): 437645E, 4552581N; CVTG16 and CVTG17 (Salitto): 501632E, 4504105N; CVTG18 (Mt Taburno): 468531E, 4549402N; CVTG19 (Maddaloni, Tunnel: 450290E, 4545491N. 

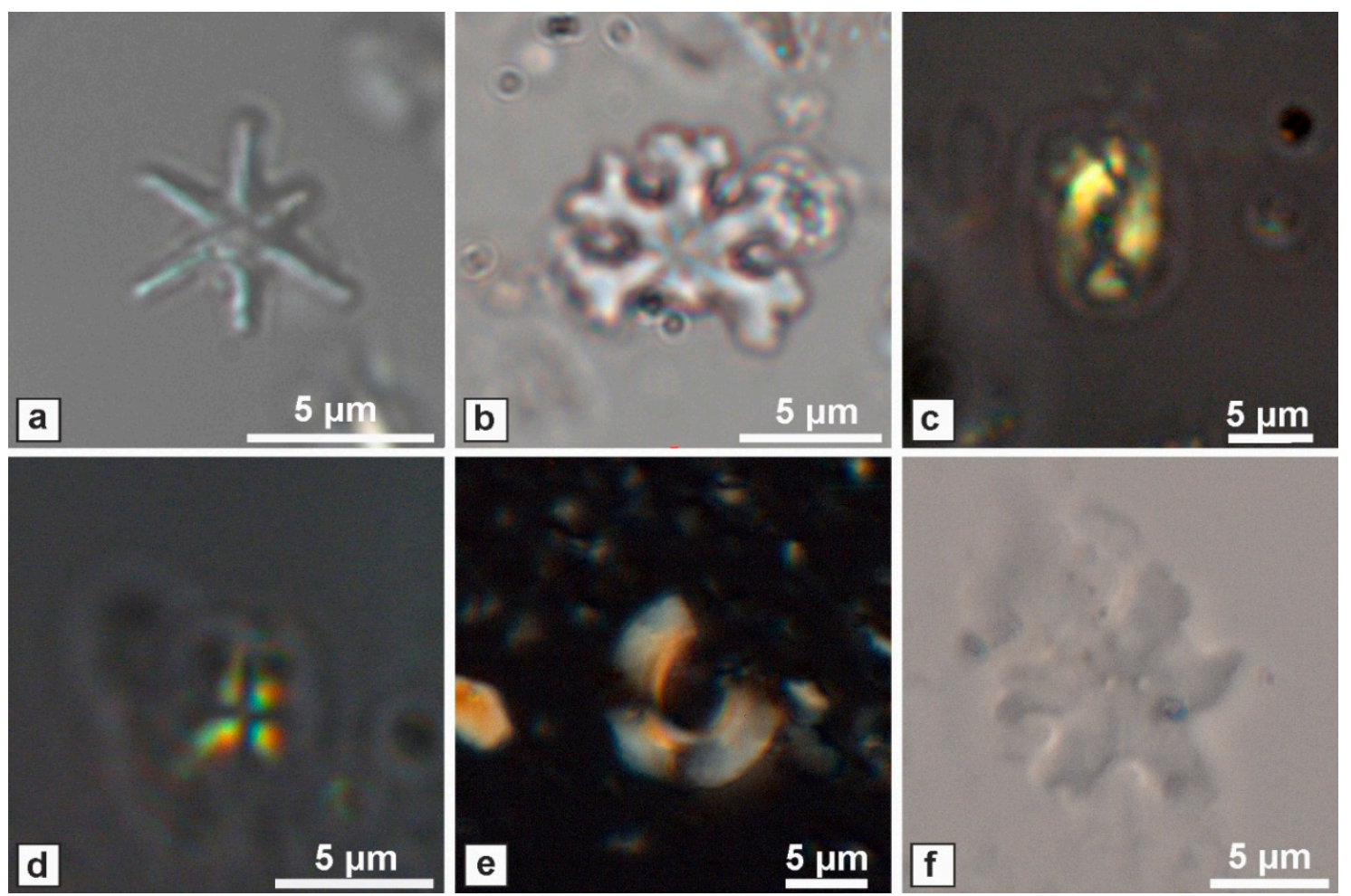

Figure 10. Microphotographs of the calcareous nannofossil species: (a) Discoaster brouweri, parallel nicols (sample CVTG 13); (b) Discoaster variabilis, parallel nicols (sample CVTG 13); (c) Helicosphaera wallichii, cross nicols (sample CVTG 9); (d) Sphenolithus abies, cross nicols (sample CVTG 3); (e) Rericulofenestra pseudoumbilicus, cross nicols (sample CVTG 4); (f) Discoaster loeblichii, parallel nicols (sample CVTG 18).

\section{Discussion}

The structural survey, carried out in several sites of the Apennine chain in the Campania region, allowed us to collect a considerable dataset of attitude and kinematic measurements of structures related to an out-of-sequence thrusting event (Figure 11). Primary and secondary structures, such as thrust faults, folds and pressure solution planes, suggest a deformation event that occurred after the deposition of the CVTG. In most of the analyzed outcrops, we observed structures associated with an NW-SE/NNE-SSW shortening (Figure 11). However, in the localities Sant'Angelo in Formis, Campagna, Pietrastornina, Pietra Maula, Mt Faggeto and Maddaloni ridge, we recognized that this deformation superposes onto structures related to an E-W/ESE-WNW directed shortening with a dominant tectonic vergence to the east (Figure 11). These two thrusting stages can be considered as out-of-sequence deformation pulses because they deform the upper Miocene CVTG deposits, whose sedimentation occurred within basins located on top of the already structured thrust sheet prism. Similar structures were also observed elsewhere in the Campania region, such as at Capri Island and the western Sorrento Peninsula [64] and Mt Massico [20]. In particular, in the first two localities, a single N-verging thrusting stage was recorded, whereas at Mt Massico, two shortening directions occur (ca. E-W and N-S), with the N-verging as the later deformation stage (Figure 11).

Further evidence of such a thrusting event is found in a tunnel excavation and by the ERT survey along the Maddaloni carbonate ridge that allowed us to reconstruct the thrust geometry in an area where it is not exposed. We interpreted the Maddaloni structure as the superposition of the out-of-sequence imbrication of different thrust sheets made of Mesozoic carbonates and CVTG deposits verging to WSW (back-thrusts), crosscut by an N-verging thrust (Figure 9f). To obtain mean values of shortening directions of the two out-of-sequence deformation stages at regional scale, we gathered all data from the PBT plots (Figure 5a-m) and those calculated for Capri Island, Sorrento Peninsula 
and Mt Massico (data from [20,64]). The resulting plot (Figure 5n) indicates the occurrence of a main cluster of the $\sigma 1$, with a direction of NNW-SSE and a secondary direction scattered between NE-SW and SE-NW. Hence, taking into account the counterclockwise rotation of ca. 20 (e.g., [67]) recorded in the Plio-Pleistocene for this sector of the southern Apennines, the shortening directions related to the two out-of-sequence episodes are ca. E-W and N-S (Figure 5o), with the latter as the more developed widespread shortening direction in the western sector of the chain.

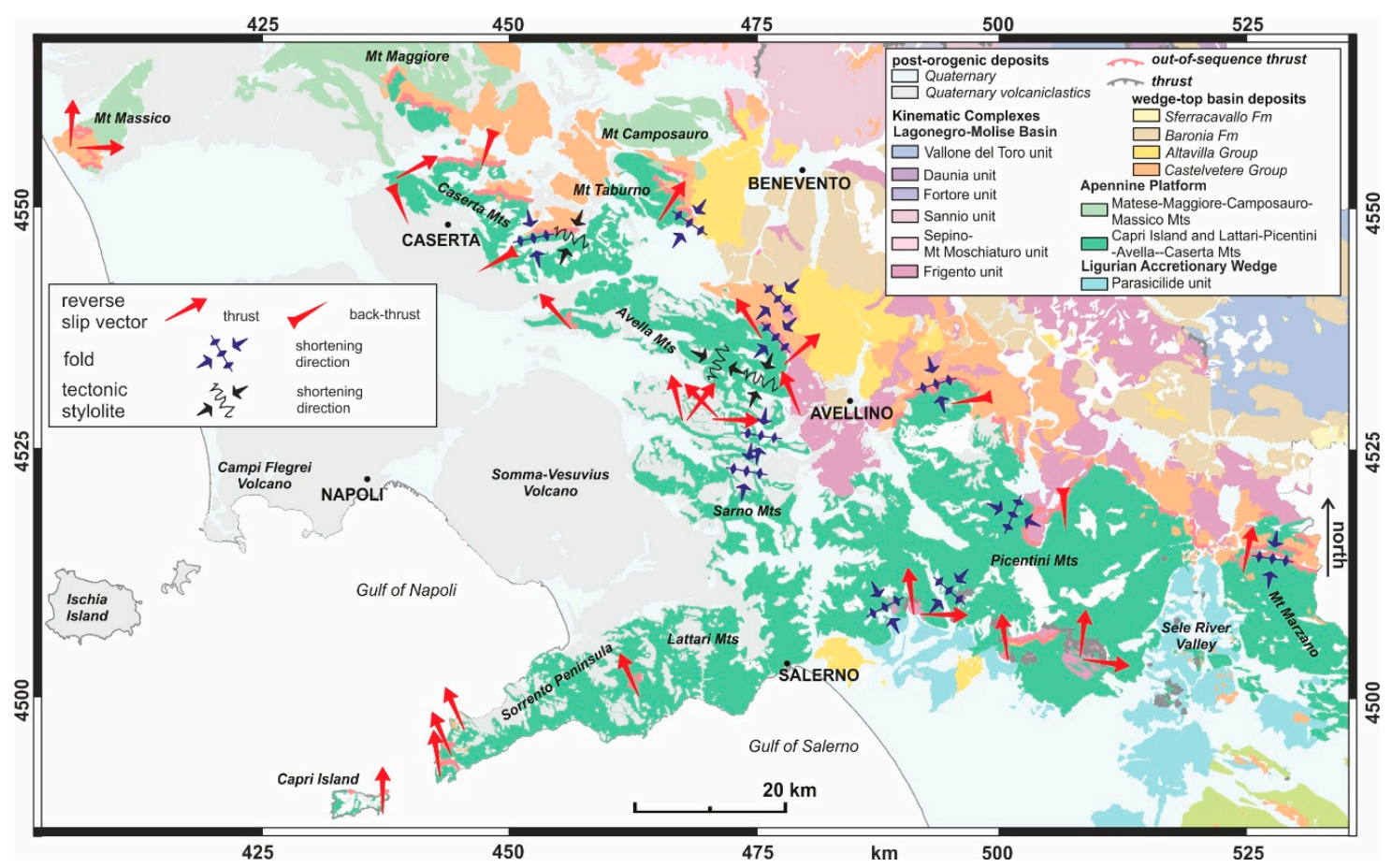

Figure 11. Tectonic map of the study area showing tectonic vergences and shortening directions for the studied out-of-sequence deformation structures.

Several papers described similar structures also in the central Apennines (e.g., [68-72]). However, a long-lived debate exists about the tectonic meaning of these structures because they frequently juxtapose younger-over-older rocks. In fact, they were interpreted as out-of-sequence thrusts (e.g., [68-74]) or low-angle normal faults (e.g., [28,75]). Contrarily to the previous orogenic area, in the southern Apennines, the occurrence of the upper Miocene CVTG deposits in the footwall of Mesozoic rocks clearly demonstrates their out-of-sequence origin. Furthermore, the exposure of these structures in several areas of the chain suggests a regional deformation event that affected a large part of the orogenic belt and not only a limited area. As concerns the age of this event, stratigraphic constraints indicate that the out-of-sequence thrusting was active following the early Messinian, the youngest age of the CVTG. We exclude that the analyzed out-of-sequence thrusting event has had an older activity because of the evidence of an extensional setting before the sedimentation of the CVTG such as what has been documented in other areas of the region (e.g., Mt Massico, [20]; Cilento, [76]) and in this study (e.g., Laviano area). It is worth noting a close analogy with the central Apennines where Tortonian-lower Messinian clastic deposits (Brecce della Renga Fm), corresponding to the CVTG rocks, were sedimented in an extensional environment before their involvement in the out-of-sequence thrusting [74].

Recently, [14] dated the E-verging out-of-sequence thrust of Mt Massico (Figure 3) to the early Pliocene (5.1 Ma) by using U-Pb geochronology on synkinematic calcite fibers. Hence, we can infer that this out-of-sequence deformation stage was successive to the deposition of CVTG (ca. 10-7 Ma) and probably active in the late Messinian-Zanclean, such as suggested for similar structures elsewhere 
located in the central Apennines and Matese area (e.g., [68-72,77]). East-verging out-of-sequence thrusts have also been reported in the eastern sector of the Campania region. In particular, these structures deform the upper Messinian-lowermost Pliocene Altavilla Group deposits (e.g., [18]) generally sealed by the lower Pliocene Baronia Fm [78]. However, in the easternmost sector of the chain (e.g., Daunia area, Figure 1), also the wedge-top basin deposits of Baronia Fm and middle Pliocene Sferracavallo Fm are deformed by such east-verging structures [79]. The eastward out-of-sequence thrusting observed in several localities is consistent with this E-W shortening that ruled the superposition of the Apennine Platform onto the Lagonegro-Molise Basin domain [20,64]. The complete closure of the Lagonegro-Molise Basin occurred with the overthrusting of the easternmost sector (Vallone del Toro succession, [25]) onto the Apulian Platform in the late Messinian-early Pliocene [19]. Subsequently, the E-W shortening, which acted, until that time, mainly through the thin-skinned tectonics, affected the buried Apulian carbonates through thick-skinned tectonics. Here, the deformation was recorded by ramp-dominate thrusts, now forming a buried imbricate belt $[80,81]$. This thick-skinned thrusting was probably triggered by the buttressing of the thick Apulian Mesozoic carbonates against the allochthonous wedge (e.g., [29]) with the positive inversion of pre-existing normal faults located within the Permo-Triassic basement (e.g., [36]). Such an interpretation has also been considered for the central and northern Apennines, where deep-rooted normal faults underwent positive inversion during the Neogene compression and thrust-fold development (e.g., [82-84]). With this in mind, the eastward out-of-sequence thrusts have to be considered as in-sequence structures enucleated at depth and crosscutting the already formed orogenic chain. These types of structures are called envelopment thrusts $[64,85,86]$. As concerns the N-S shortening direction, we suggest that it could be considered as related to lateral ramps of the main frontal E-verging thrusts. Figure 12 shows a tectono-stratigraphic evolution scheme of the analyzed area in the Serravallian-early Pliocene interval. From the Serravallian-early Tortonian, the Apennine Platform overthrusted onto the Lagonegro-Molise Basin successions, forming an imbricate fan of thrust sheets in the footwall (Figure 12a). Subsequently, in the late Tortonian-early Messinian, the CVTG sediments deposited within wedge-top basins on top of the tectonic pile, sealing the in-sequence tectonic contacts (Figure 12b). The sedimentation was preceded by an extensional event recorded by normal faults. In the late Messinian-early Pliocene, out-of-sequence thrusts have developed as the positive inversion of deep-seated normal faults (Figure 12c,d) with a main eastward tectonic transport and the formation of lateral ramps with $\mathrm{N}$ and $\mathrm{S}$ vergences.
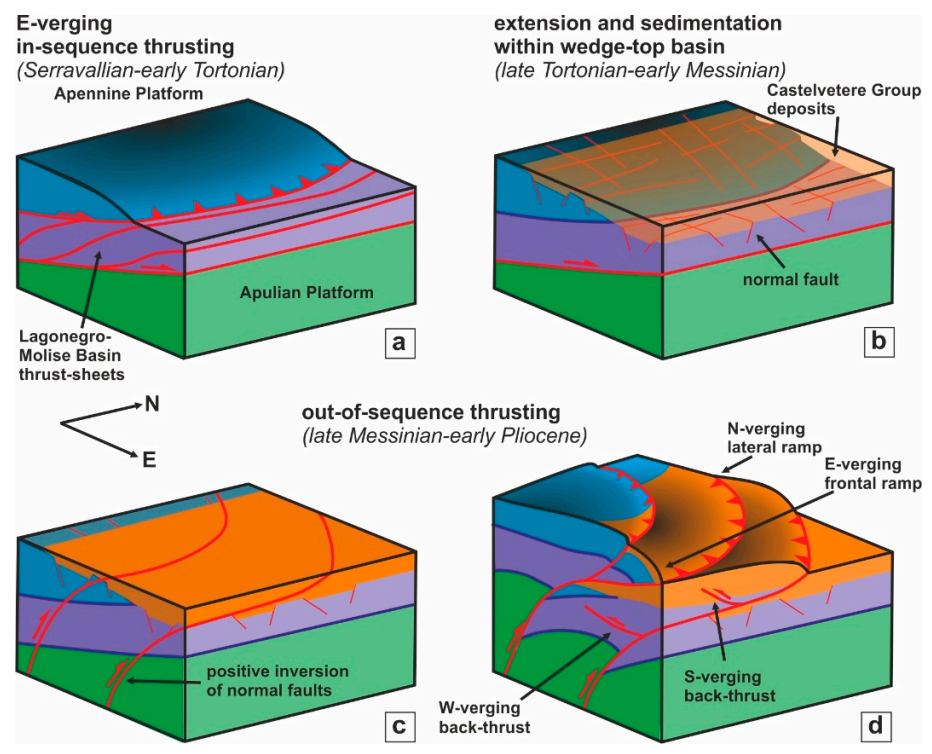

Figure 12. (a-d) Cartoon showing the tectono-stratigraphic evolution scheme of the analyzed area between the Serravallian and early Pliocene. 


\section{Conclusions}

Our study reports the occurrence of a regional tectonic event during the late Messinian-early Pliocene defined by out-of-sequence thrusting. The main thrust, related to this event, is exposed along the N-NE flank of the carbonate ridges forming the mountain backbone of the Campania region. This out-of-sequence thrust juxtaposed the Meso-Cenozoic Apennine Platform carbonates onto its margin (e.g., Laviano and Mt Croce successions) or onto the Frigento unit (Lagonegro-Molise Basin unit), with the interposition, in both cases, of the upper Miocene wedge-top basin deposits of the CVTG. The main thrust is marked by a ramp anticline exposed in few localities such as the areas of Chiusano-Castelvetere and Pietrastornina. We studied the main thrust only in few places, whereas several secondary structures are common both in the hanging wall and footwall. The structural analysis indicates two main shortening directions: ca. E-W and N-S. Thanks to the use of the electrical resistivity tomography and information obtained following a tunnel excavation, the evidence of such a main thrusting event is given in an area where the thrust is not exposed. The age of this tectonic event is younger than the age of the CVTG sediments, whose dating of upper Tortonian-lower Messinian is confirmed by the nannoplankton analysis performed in this study. Similar structures described in other studies in the whole southern and central Apennines have been dated to the late Messinian-early Pliocene. These out-of-sequence thrust faults are the surficial expression of deep-seated ramp thrusts formed as a positive inversion of normal faults located in the Permo-Triassic basement. These envelopment thrusts developed from west to east of the chain, involving younger and younger wedge-top basin deposits, from the late Miocene to the late Pliocene, respectively.

Author Contributions: Conceptualization, S.V., R.D.M., S.C.; methodology, S.V., E.P.P., F.D.A., C.D.P., R.D.M., E.P., M.S.; software, E.P.P., F.D.T., C.D.P., R.D.M., E.P.; validation, S.V., S.C.; formal analysis, E.P.P., F.D.T., C.D.P., R.D.M., E.P., M.S.; investigation, S.V., E.P.P., F.D.T., C.D.P., P.N., S.C.; resources, S.V, S.C., R.D.M.; data curation, E.P.P., F.D.T., C.D.P., R.D.M., E.P., M.S.; writing—original draft preparation, S.V., R.D.M., M.S., J.N., S.C.; writing一review and editing, S.V., R.D.M., M.S., S.C.; visualization, S.V., E.P.P., M.S. All authors have read and agreed to the published version of the manuscript.

Funding: This research received no funding.

Acknowledgments: We thank the editor G. Wang and the guest editors D. Liotta, G. Molli and A. Cipriani for the opportunity to share our research in the Special Issue "The Apennines: Tectonics, Sedimentation, and Magmatism from the Palaeozoic to the Present". We are grateful to the two reviewers L. Aldega and P. Pace, for the useful suggestions and corrections that improved the final version of the manuscript. We thank the Consorzio CANCELLO FRASSO TELESINO (CFT) for the permission to publish the ERT and well log data, access to the tunnel excavation and use photos of the front-excavation. Finally, we thank G. Vespasiano and F. Ferraro for the help in the field.

Conflicts of Interest: The author declares no conflict of interest.

\section{References}

1. Hippolyte, J.C.; Angelier, J.; Roure, F. A major geodynamic change revealed by Quaternary stress patterns in the southern Apennines (Italy). Tectonophysics 1994, 230, 199-210. [CrossRef]

2. Schiattarella, M. Quaternary tectonics of the Pollino Ridge, Calabria-Lucania boundary, Southern Italy. In Continental Transpressional and Transtensional Tectonics; Holdsworth, R.E., Strachan, R.A., Dewey, J.F., Eds.; Geological Society of London: London, UK, 1998; Volume 135, pp. 341-354.

3. Ascione, A.; Cinque, A.; Improta, L.; Villani, F. Late quaternary faulting within the southern Apennines seismic belt: New data from Mt. Marzano area (southern Italy). Quat. Int. 2003, 101, 27-41. [CrossRef]

4. Ferranti, L.; Santoro, E.; Mazzella, M.E.; Monaco, C.; Morelli, D. Active transpression in the northern Calabria Apennines, southern Italy. Tectonophysics 2009, 476, 226-251. [CrossRef]

5. Brozzetti, F. The Campania-Lucania Extensional Fault System, southern Italy: A suggestion for a uniform model of active extension in the Italian Apennines. Tectonics 2011, 30, TC5009. [CrossRef]

6. Capaldi, G.; Cinque, A.; Romano, P. Ricostruzione di sequenze morfoevolutive nei Picentini meridionali (Campania, Appennino meridionale). Geogr. Fis. Din. Quat. 1988, 1, $207-222$.

7. Cinque, A.; Guida, F.; Russo, F.; Santangelo, N. Dati cronologici e stratigrafici su alcuni depositi continentali della Piana del F. Sele: I Conglomerati di Eboli. Geogr. Fis. Din. Quat. 1988, 1, 39-44. 
8. Coltorti, M.; Dramis, F. The chronology of Upper Pleistocene stratified slope-waste-deposits in Central Italy. Permafr. Periglac. Processes 1995, 6, 235-242. [CrossRef]

9. Santangelo, N.; Di Donato, V.; Lebreton, V.; Romano, P.; Russo Ermolli, E. Palaeolandscapes of Southern Apennines during the late Early and the Middle Pleistocene. Quat. Int. 2012, 267, 20-29. [CrossRef]

10. Cioni, R.; Isaia, R.; Sulpizio, R. The city of Napoli and its active volcanoes. Geol. Field Trips 2019. [CrossRef]

11. Haines, S.; Lynch, E.; Mulch, A.; Valley, J.W.; Van der Pluijm, B. Meteoric fluid infiltration in crustalscale normal fault systems as indicated by $\delta 18 \mathrm{O}$ and $\delta 2 \mathrm{H}$ geochemistry and $40 \mathrm{Ar} / 39 \mathrm{Ar}$ dating of neoformed clays in brittle fault rocks. Lithosphere 2016, 8, 587-600. [CrossRef]

12. Viola, G.; Torgersen, E.; Mazzarini, F.; Musumeci, G.; Van der Lelij, R.; Schönenberger, J.; Garofalo, P.S. New Constraints on the Evolution of the Inner Northern Apennines by K-Ar Dating of Late Miocene-Early Pliocene Compression on the Island of Elba, Italy. Tectonics 2018, 37, 3229-3243. [CrossRef]

13. Aldega, L.; Viola, G.; Casas-Sainz, A.; Marcén, M.; Román-Berdiel, T.; Lelij, R. Unraveling Multiple Thermotectonic Events Accommodated by Crustal-Scale Faults in Northern Iberia, Spain: Insights From K-Ar Dating of Clay Gouges. Tectonics 2019, 38, 1-23. [CrossRef]

14. Smeraglia, L.; Aldega, L.; Billi, A.; Carminati, E.; Di Fiore, F.; Gerdes, A.; Rossetti, F.; Vignaroli, G. Development of an Intrawedge Tectonic Mélange by Out-of-Sequence Thrusting, Buttressing, and Intraformational Rheological Contrast, Mt. Massico Ridge, Apennines, Italy. Tectonics 2019, 38, 1223-1249. [CrossRef]

15. Carminati, E.; Aldega, L.; Smeraglia, L.; Scharf, A.; Mattern, F.; Albert, R.; Gerdes, A. Tectonic evolution of the Northern Oman Mountains, part of the Strait of Hormuz Syntaxis: New structural and paleothermal analyses and $\mathrm{U}-\mathrm{Pb}$ dating of synkinematic calcite. Tectonics 2020, 39, e2019TC005936. [CrossRef]

16. Carboni, F.; Viola, G.; Aldega, L.; Van der Lelij, R.; Brozzetti, F.; Barchi, M.R. K-Ar fault gouge dating of Neogene thrusting: The case of the siliciclastic deposits of the Trasimeno Tectonic Wedge (Northern Apennines, Italy). Ital. J. Geosci. 2020, 139, 300-308. [CrossRef]

17. Curzi, M.; Aldega, L.; Bernasconi, S.M.; Berra, F.; Billi, A.; Boschi, C.; Franchini, S.; Van der Lelij, R.; Viola, G.; Carminati, E. Architecture and evolution of an extensionally-inverted thrust (Mt. Tancia Thrust, Central Apennines): Geological, structural, geochemical, and K-Ar geochronological constraints. J. Struct. Geol. 2020, 136, 104059. [CrossRef]

18. Vitale, S.; Ciarcia, S. Tectono-stratigraphic and kinematic evolution of the southern Apennines/CalabriaPeloritani Terrane system (Italy). Tectonophysics 2013, 583, 164-182. [CrossRef]

19. Vitale, S.; Ciarcia, S. Tectono-stratigraphic setting of the Campania region (southern Italy). J. Maps 2018, 14, 9-21. [CrossRef]

20. Vitale, S.; Prinzi, E.P.; Ciarcia, S.; Sabbatino, M.; Tramparulo, F.D.A.; Verazzo, G. Polyphase out-of-sequence thrusting and occurrence of marble detritus within the wedge-top basin deposits in the Mt. Massico (southern Apennines): Insights into the late Miocene tectonic evolution of the central Mediterranean. Int. J. Earth Sci. 2019, 108, 501-519. [CrossRef]

21. Pappone, G.; Ferranti, L. Thrust tectonics in the Picentini Mountains, Southern Apennines, Italy. Tectonophysics 1995, 252, 331-348. [CrossRef]

22. Carminati, E.; Lustrino, M.; Doglioni, C. Geodynamic evolution of the central and western Mediterranean: Tectonics vs. igneous petrology constraints. Tectonophysics 2012, 579, 173-192. [CrossRef]

23. Malinverno, A.; Ryan, W.B.F. Extension in the Tyrrhenian Sea and shortening in the Apennines as result of arc migration driven by sinking of the lithosphere. Tectonics 1986, 5, 227-245. [CrossRef]

24. Vitale, S.; Ciarcia, S.; Fedele, L.; Tramparulo, F.D.A. The Ligurian oceanic successions in southern Italy: The key to decrypting the first orogenic stages of the southern Apennines-Calabria chain system. Tectonophysics 2019, 750, 243-261. [CrossRef]

25. Bonardi, G.; Ciarcia, S.; Di Nocera, S.; Matano, F.; Sgrosso, I.; Torre, M. Carta delle principali unità cinematiche dell'Appennino meridionale. Nota illustrativa. Ital. J. Geosci. 2009, 128, 47-60.

26. Vitale, S.; Dati, F.; Mazzoli, S.; Ciarcia, S.; Guerriero, V.; Iannace, A. Modes and timing of fracture network development in poly-deformed carbonate reservoir analogues, Mt. Chianello, southern Italy. J. Struct. Geol. 2012, 37, 223-235. [CrossRef]

27. D'Argenio, B.; Pescatore, T.; Scandone, P. Schema geologico dell'Appennino meridionale (Campania e Lucania). Atti del Conv. Moderne vedute sulla geologia dell'Appennino. Atti Accad. Naz. Lincei 1973, 182, $49-72$. 
28. Mostardini, F.; Merlini, S. Appennino centro-meridionale: Sezioni Geologiche e proposta di modello strutturale. Mem. Soc. Geol. Ital. 1986, 35, 177-202.

29. Mazzoli, S.; D'Errico, M.; Aldega, L.; Corrado, S.; Invernizzi, C.; Shiner, P.; Zattin, M. Tectonic burial and 'young' (<10 Ma) exhumation in the southern Apennines fold and thrust belt (Italy). Geology 2008, 36, 243-246.

30. Sabbatino, M.; Vitale, S.; Tavani, S.; Consorti, L.; Corradetti, A.; Cipriani, A.; Arienzo, I.; Parente, M. Constraining the onset of flexural subsidence and peripheral bulge extension in the Miocene foreland of the southern Apennines (Italy) by Sr-isotope stratigraphy. Sediment. Geol. 2020, 401, 105634. [CrossRef]

31. Mattioni, L.; Shiner, P.; Tondi, E.; Vitale, S.; Cello, G. The Argille Varicolori Unit of Lucania (Italy): A record of tectonic offscraping and gravity sliding in the Mesozoic-Tertiary Lagonegro Basin, southern Apennines. In Geology and Active Tectonics of the Western Mediterranean Region and North Africa; Moratti, G., Chalouan, A., Eds.; Geological Society of London: London, UK, 2006; Volume 262, pp. 277-288.

32. Handy, M.R.; Schmid, S.M.; Bousquet, R.; Kissling, E.; Bernoulli, D. Reconciling platetectonic reconstructions of Alpine Tethys with the geological-geophysical record of spreading and subduction in the Alps. Earth-Science Rev. 2010, 102, 121-158. [CrossRef]

33. Ciarcia, S.; Mazzoli, S.; Vitale, S.; Zattin, M. On the tectonic evolution of the Ligurian accretionary complex in southern Italy. GSA Bull 2012, 124, 463-483. [CrossRef]

34. Vitale, S.; Ciarcia, S.; Tramparulo, F.D.A. Deformation and stratigraphic evolution of the Ligurian Accretionary Complex in the southern Apennines (Italy). J. Geodyn. 2013, 66, 120-133. [CrossRef]

35. Ciarcia, S.; Vitale, S. Sedimentology, stratigraphy and tectonics of evolving wedge-top depozone: Ariano Basin, southern Apennines, Italy. Sediment. Geol. 2013, 290, 27-46. [CrossRef]

36. Shiner, P.; Beccacini, A.; Mazzoli, S. Thin-skinned versus thick-skinned structural models for Apulian Carbonate Reservoirs: Constraints from the Val D'Agri Fields. Mar. Pet. Geol. 2004, 21, 805-827. [CrossRef]

37. Ciarcia, S.; Vitale, S.; Di Staso, A.; Iannace, A.; Mazzoli, S.; Torre, M. Stratigraphy and tectonics of an internal unit of the Southern Apennines: Implications for the geodynamic evolution of the peri-Tyrrhenian mountain belt. Terra Nova 2009, 21, 88-96. [CrossRef]

38. Vitale, S.; Amore, O.F.; Ciarcia, S.; Fedele, L.; Grifa, C.; Prinzi, E.P.; Tavani, S.; Tramparulo, F.D.A. Structural, stratigraphic and petrological clues for a Cretaceous-Paleogene abortive rift in the southern Adria domain (southern Apennines, Italy). Geol. J. 2018, 53, 660-681. [CrossRef]

39. Scandone, P. Studi di geologia lucana; la serie calcareo silico marnosa e i suoi rapporti con l'Appennino calcareo. Boll. Soc. Nat. Napoli 1967, 76, 301-469.

40. Scandone, P. Studi di Geologia lucana: Carta dei terreni della serie calcareo-silico-marnosa e note illustrative. Boll. Soc. Nat. Napoli 1972, 81, 225-300.

41. Scandone, P.; Sgrosso, I.; Vallario, A. Finestra tettonica nella serie calcareo-silico-marnosa lucana presso Campagna (Monti Picentini, Salerno). Boll. Soc. Nat. Napoli 1967, 76, 3-10.

42. Turco, E. La finestra tettonica di Campagna (M. Picentini, Salerno). Boll. Soc. Nat. Napoli 1976, 85, $639-665$.

43. ISPRA. Carta Geologica d'Italia Alla Scala 1:50.000, Foglio 468 “Eboli”. Available online: http://www. isprambiente.gov.it/Media/carg/468_EBOLI/Foglio.html (accessed on 4 July 2020).

44. Angelier, J.; Mechler, P. Sur une méthode graphique de recherche des contraintes principales également utilisable en tectonique et en séismologie: La méthode des diédres droits. Bull. Soc. Geol. Fr. 1977, 19, 1309-1318. [CrossRef]

45. Angelier, J. Determination of the mean principal directions of stresses for a given fault population. Tectonophysics 1979, 56, T17-T26. [CrossRef]

46. Reiter, F.; Acs, P.; Tectonics, F.P. Software for Structural Geology. Innsbruck University: Innsbruck, Austria, 1996-2017. Available online: http://www.tectonicsfp.com (accessed on 4 July 2020).

47. Bown, P.R.; Young, J.R. Techniques. In Calcareous Nannofossil Biostratigraphy; Bown, P.R., Ed.; Springer: Dordrecht, The Netherlands, 1998; pp. 16-28.

48. Reynolds, J.M. An Introduction to Applied and Environmental Geophysics, 2nd ed.; Wiley: Chichester, UK, 2011; p. 688. ISBN 978-0-471-48535-3.

49. Di Maio, R.; Patella, D.; Petrillo, Z.; Siniscalchi, A.; Cecere, G.; De Martino, P. Application of electric and electromagnetic methods to the definition of the Campi Flegrei caldera (Italy). Ann. Geophys. 2000, 43, 375-390. 
50. Park, S.K.; Wernicke, B. Electrical conductivity images of quaternary faults and tertiary detachments in the California basin and range. Tectonics 2003, 22, 1030. [CrossRef]

51. Koukadaki, M.A.; Karatzas, G.P.; Papadopoulou, M.P.; Vafidis, A. Identification of the saline zone in a coastal aquifer using electrical tomography data and simulation. Water Resour. Manag. 2007, 21, 1881-1898. [CrossRef]

52. Vanneste, K.; Verbeeck, K.; Petermans, T. Pseudo-3D imaging of a low-slip-rate, active normal fault using shallow geophysical methods: The Geleen fault in the Belgian Maas River valley. Geophysics 2008, 73, B1-B9. [CrossRef]

53. Giocoli, A.; Galli, P.; Giaccio, B.; Lapenna, V.; Messina, P.; Peronace, E.; Romano, G.; Piscitelli, S. Electrical resistivity tomography across the Paganica-San Demetrio fault system (L'Aquila 2009 earthquake). Boll. Geofis. Teor. Appl. 2011, 52, 457-469.

54. Giocoli, A.; Magrì, C.; Vannoli, P.; Piscitelli, S.; Rizzo, E.; Siniscalchi, A.; Basso, C.; Di Nocera, S. Electrical Resistivity Tomography investigations in the Ufita Valley (Southern Italy). Ann. Geophys. 2008, 51, 213-223.

55. Seminsky, K.Z.; Zaripov, R.M.; Olenchenko, V.V. Interpretation of shallow electrical resistivity images of faults: Tectonophysical approach. Russ. Geol. Geophys. 2016, 57, 1349-1358. [CrossRef]

56. Lecocq, T.; Camelbeeck, T. Electrical resistivity tomography data across the Hockai Fault Zone (Ardenne, Belgium). Data in Brief 2017, 11, 1-4. [CrossRef]

57. Loke, M.H. Tutorial: 2-D and 3-D Electrical Imaging Surveys; Geotomo Software: Penang, Malaysia, 2001.

58. Bravi, S.; Civile, D.; Martino, C.C.; Putignano, M.L. La struttura da interferenza nei carbonati mesozoici della dorsale di Monte Fellino (Appennino Campano). Boll. Soc. Geol. Ital. 2006, 125, 105-116.

59. ISPRA. Servizio Geologico d'Italia. Geological Map of Italy, Scale 1:100,000, Sheet 171 Gaeta. Available online: http://193.206.192.231/carta_geologica_italia/tavoletta.php?foglio=171 (accessed on 4 July 2020).

60. Pescatore, T.; Sgrosso, I. I rapporti tra la Piattaforma Campano-Lucana e la Piattaforma Abruzzese-Campana nel casertano. Boll. Soc. Geol. Ital. 1973, 92, 925-938.

61. Martini, E. Standard Tertiary and Quaternary calcareous nannoplankton zonation. In Proceedings of the Second Planktonic Conference; Farinacci, A., Ed.; Tecnoscienza: Roma, Italy, 1971; Volume 2, pp. 739-765.

62. Okada, H.; Bukry, D. Supplementary modification and introduction of code numbers to the low-latitude coccolith biostratigraphic zonation (Bukry 1973, 1975). Mar. Micropaleontol. 1980, 5, 321-325. [CrossRef]

63. Backman, J.; Raffi, I.; Rio, D.; Fornaciari, E.; Pälike, H. Biozonation and biochronology of Miocene through Pleistocene calcareous nannofossils from low and middle latitudes. Newsletters Strat. 2012. [CrossRef]

64. Vitale, S.; Tramparulo, F.D.A.; Ciarcia, S.; Amore, F.O.; Prinzi, E.P.; Laiena, F. The northward tectonic transport in the southern Apennines: Examples from the Capri Island and western Sorrento Peninsula (Italy). Int. J. Earth Sci. 2017, 106, 97-113. [CrossRef]

65. Pescatore, T.; Sgrosso, I.; Torre, M. Lineamenti di tettonica e sedimentazione nel Miocene dell'Appennino campano-lucano. Mem. Soc. Nat. Napoli 1970, 78, 337-408.

66. Critelli, S.; Le Pera, E. Tectonic evolution of the southern Apennines Thrust-Belt (Italy) as reflected in modal compositions of Cenozoic sandstone. J. Geol. 1995, 103, 95-105. [CrossRef]

67. Gattacceca, J.; Speranza, F. Paleomagnetic constraints for the tectonic evolution of the southern Apennines belt (Italy). Boll. Soc. Geol. Ital. 2007, 7, 39-46.

68. Cerisola, R.; Montone, P. Analisi strutturale di un settore della catena dei Monti Ausoni-Aurunci (Lazio, Italia centrale). Boll. Soc. Geol. Ital. 1992, 111, 449-457.

69. Naso, G.; Tallini, M.; Tozzi, M. Caratteristiche geologico-strutturali dell'area di Miranda (Isernia): Un contributo alla comprensione dei rapporti tra le falde molisane e avanfossa del Messiniano-Pliocene inferiore. Mem. Soc. Geol. Ital. 1995, 114, 423-441.

70. Scrocca, D.; Tozzi, M.; Parotto, M. Assetto strutturale del settore compreso tra il Matese, le Mainarde e l'Unità di Frosolone. Implicazioni per l'evoluzione neogenica del sistema di sovrascorrimento nell'Appennino centro-meridionale. Studi Geol. Camerti 1995, 2, 407-418.

71. De Corso, S.; Scrocca, D.; Tozzi, M. Geologia dell'anticlinale del Matese e implicazioni per la tettonica dell'Appennino molisano. Boll. Soc. Geol. Ital. 1998, 117, 419-441.

72. Sani, F.; Del Ventisette, C.; Montanari, D.; Coli, M.; Nafissi, P.; Piazzini, A. Tectonic evolution of the internal sector of the Central Apennines, Italy. Mar. Pet. Geol. 2004, 21, 1235-1254. [CrossRef]

73. Ghisetti, F.; Vezzani, L. Thrust belt development in the Central Apennines: Northward polarity of thrusting and out-of-sequence deformations in the Gran Sasso chain (Italy). Tectonics 1991, 10, 904-919. [CrossRef] 
74. Carminati, E.; Fabbi, S.; Santantonio, M. Slab bending, syn-subduction normal faulting, and out-of-sequence thrusting in the Central Apennines. Tectonics 2014, 33, 530-551. [CrossRef]

75. Pace, P.; Domenica, A.D.; Calamita, F. Summit low-angle faults in the Central Apennines of Italy: Younger on-older thrusts or rotated normal faults? Constraints for defining the tectonic style of thrust belts. Tectonics 2014, 33, 756-785. [CrossRef]

76. Corrado, S.; Aldega, L.; Perri, F.; Critelli, S.; Muto, F.; Schito, A.; Tripodi, V. Detecting syn-orogenic extension and sediment provenance of the Cilento wedge top basin (southern Apennines, Italy): Mineralogy and geochemistry of fine-grained sediments and petrography of dispersed organic matter. Tectonophysics 2019, 750, 404-418. [CrossRef]

77. Scrocca, D.; Tozzi, M. Tettogenesi mio-pliocenica dell'Appennino molisano. Boll. Soc. Geol. Ital. 1999, 118, 255-286.

78. ISPRA. Carta Geologica d'Italia Alla Scala 1:50.000, Foglio 433 “Ariano Irpino". Available online: http: //www.isprambiente.gov.it/Media/carg/433_ARIANO_IRPINO/Foglio.html (accessed on 4 July 2020).

79. Dazzaro, L.; Di Nocera, S.; Pescatore, T.; Rapisardi, L.; Romeo, M.; Russo, B.; Senatore, M.R.; Torre, M. Geologia del margine della catena appenninica tra il F. Fortore ed il T. Calaggio (Monti della Daunia-Appennino Meridionale). Mem. Soc. Geol. Ital. 1988, 41, 411-422.

80. Mazzoli, S.; Barkham, S.; Cello, G.; Gambini, R.; Mattioni, L.; Shiner, P.; Tondi, E. Reconstruction of continental margin architecture deformed by the contraction of the Lagonegro Basin, southern Apennines, Italy. J. Geol. Soc. Lond. 2001, 158, 309-319. [CrossRef]

81. Ascione, A.; Ciarcia, S.; Di Donato, V.; Mazzoli, S.; Vitale, S. The Pliocene-Quaternary wedge-top basins of southern Italy: An expression of propagating lateral slab tear beneath the Apennines. Basin Res. 2012, 24, 456-474. [CrossRef]

82. Pace, P.; Calamita, F. Push-up inversion structures v. fault-bend reactivation anticlines along oblique thrust ramps: Examples from the Apennines fold-and-thrust belt (Italy). J. Geol. Soc. Lond 2014, 171, 227-238. [CrossRef]

83. Scisciani, V.; Patruno, S.; Tavarnelli, E.; Calamita, F.; Pace, P.; Iacopini, D. Multi-phase reactivations and inversions of Paleozoic-Mesozoic extensional basins during the Wilson cycle: Case studies from the North Sea (UK) and the Northern Apennines (Italy). In Fifty Years of the Wilson Cycle Concept in Plate Tectonics; Wilson, R.W., Houseman, G.A., Mccaffrey, K.J.W., Doré, A.G., Buiter, S.J.H., Eds.; Geological Society of London: London, UK, 2019; Volume 470, pp. 205-243.

84. Scisciani, V.; Agostini, S.; Calamita, F.; Pace, P.; Cilli, A.; Giori, I.; Paltrinieri, W. Positive inversion tectonics in foreland fold-and-thrust belts: A reappraisal of the Umbria-Marche Northern Apennines (Central Italy) by integrating geological and geophysical data. Tectonophysics 2014, 637, 218-237. [CrossRef]

85. Bally, A.W.; Gordy, P.L.; Stewart, G.A. Structure, seismic data and orogenic evolution of the southern Canadian Rocky Mountains. Bull. Can. Pet. Geol. 1966, 14, 337-381.

86. Ghisetti, F.; Barchi, M.; Bally, A.W.; Moretti, I.; Vezzani, L. Conflicting balanced structural sections across the Central Apennines (Italy): Problems and implications. In Generation, Accumulation and Production of Europe's Hydrocarbons; Spencer, A.M., Ed.; Springer: Berlin/Heidelberg, Germany, 1993; Volume 3, pp. 219-231.

(C) 2020 by the authors. Licensee MDPI, Basel, Switzerland. This article is an open access article distributed under the terms and conditions of the Creative Commons Attribution (CC BY) license (http://creativecommons.org/licenses/by/4.0/). 